\title{
Evaporation Studies of Simulated Low-Heat Waste and Post-Aluminum Dissolution Waste
}

by

M. J. Barnes

Westinghouse Savannah River Company

Savannah River Site

Aiken, South Carolina 29808

G. T. Chandler

DOE Coniract No. DE-AC09-89SR18035

This paper was prepared in connection with work done under the above contract number with the U.S. Department of Energy. By acceptance of this paper, the publisher and/or recipient acknowledges the U.S. Government's right to retain a nonexclusive, royalty-free license in and to any copyright covering this paper, along with the right to reproduce and to authorize others to reproduce all or part of the copyrighted paper. 


\section{DISCLAIMER}

This report was prepared as an account of work sponsored by an agency of the United States Government. Neither the United States Government nor any agency thereof, nor any of their employees, makes any warranty, express or implied, or assumes any legal liability or responsibility for the accuracy, completeness, or usefulness of any information, apparatus, product, or process disclosed, or represents that its use would not infringe privately owned rights. Reference herein to any specific commercial product, process, or service by trade name, trademark, manufacturer, or otherwise does not necessarily constitute or imply its endorsement, recommendation, or favoring by the United States Government or any agency thereof. The views and opinions of authors expressed herein do not necessarily state or reflect those of the United States Government or any agency thereof.

This report has been reproduced directly from the best available copy.

Available to DOE and DOE contractors from the Office of Scientific and Technical Information, P. O. Box 62, Oak Ridge, TN 37831; prices available from (423) 576-8401.

Available to the public from the National Technical Information Service, U. S. Department of Commerce, 5285 Port Royal Road, Springfield, VA 22161. 


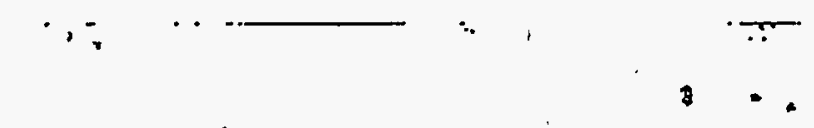

COPY DISTRIBUTION FOR WSRC-RP-94-251

March 4, 1994

EVAPORATION STUDIES OF SIMULATED LOW-HEAT WASTE AND POST-ALUMINUM DISSOLUTION WASTE (U)

cc: $\quad$ G.T, Wright, 703-H

T.M. Monahon, 703-H

R.A. Scaggs, 703-H

J.P Morin, 719-4A

R.G. Croley, 241-120H

J.N. Brooke, 241-120H

W.E. VanPelt, 241-152H

D.C. Wood, 706-21C

P. Rutland, 241-152H

J.E. Marra, 703-H

M.C. Chandler, 703-HI

J.S. Clemmons, 703-H

G.K. Georgeton, 703-H

P.D. d'Entremont, 703-H

C. Bess, 703-H

P.L. Gray, 703-H

D.F. Brown, 703-H

W.R. Jacobsen, 703-10C

L.M. Papouchado, 773-A

J.D. Cohen, 730-A

W.L. Tamosaitis, 773-A

A.L. Blancett, 773-A

T.L. Capeletti, 773-41A

N.C. Iyer, 773-A

D.T. Hobbs, 773-A

W.S. Cavin, 773-A

D.D. Walker, 773-A

N.E. Bibler, 773-A

M.C. Thompson, 773-A

D.G. Karraker, 773-A

A.Q. Goslen, 773-22A

B.J. Wiersma, 773-A

TIM, 703-43A

IWT-LWP File, 773-A 


\section{DISCLAIMER}

\section{Portions of this document may be illegible electronic image products. Images are produced from the best available original document.}




\section{WESTINGHOUSE SAVANNAH RIVER COMPANY} SAVANNAH RIVER TECHNOLOGY CENTER

\section{8}

WSRC-RP-94-251

Keywords: Waste Evaporation, High-level waste, Criticality, ITP, Uranium

March 4, 1994

To: S.D. Fink, 773-A

From: M.J. Barnes and G,T. Chandler

Technical Reviewer:

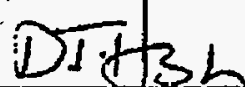

D.T. Hobbs

\section{EVAPORATION STUDIES OF SIMULATED LOW-HEAT WASTE AND POST-ALUMIINUM DISSOLUTION WASTE (U)}

\section{SUMMARY}

Successive evaporations were performed on simulated low-heat waste and post-aluminum dissolution waste spiked with depleted uranium. Waste compositions were determined for supernate and saltcake samples. Approximately $42 \mathrm{wt} \%$ of the total uranium in the low-heat waste precipitated as uranium solids or was present as dissolved uranium in interstitial liquid. Numerical analysis of the data results in an estimate that only 10 wt \% of the total uranium was undissolved and the remainder was dissolved uranium in interstitial liquid. Approximately $68 \mathrm{wt} \%$ of the total uranium in the post-aluminum dissolution waste precipitated as uranium solids or was present as dissolved uranium in interstitial liquid. Numerical analysis of the data results in an estimate that only 52 wt \% of the total uranium was undissolved and the remainder was dissolved uranium in interstitial liquid. Additional dissolution studies will be performed that are directly applicable to Tank 4 itH.

\section{INTRODUCTION}

Carbon-steel tanks are used at the Savannah River Site for the interim storage of nuclear waste. The waste consists of two phases: a sludge and its associated supernate. The solution is strongly alkaline with a high salt content (i.e., sodium nitrate, nitrite, aluminate, etc.). To minimize the volume of waste, the supernatant solution is evaporated and stored as a mixture of concentrated liquid and crystalline solids. The evaporation process consists of successive heating and cooling of the solution. During

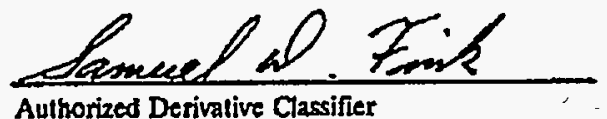


heating, water is evaporated resulting in salt saturation of the solution. Upon cooling, salts, in excess of their solubility at the lower temperature, crystallize forming a saltcake layer. The residual supernate is then reprocessed to repeat the cycle. This process is repeated with the supernate solution until the waste tank is filled with saltcake and a minimal volume of saturated supernate.

Final disposal of the saltcake will be accomplished by dissolution of the saltcake and processing through the Defense Waste Processing Facility (DWPF). Decontamination of the high-level radioactive waste solutions will be accomplished by the precipitation of cesium and potassium with sodium tetraphenylborate and adsorption of strontium by monosodium titanate in the In-Tank Precipitation (ITP) process. The slurry will be concentrated by filtration and washed. The resulting decontaminated salt solution filtrate will be stabilized in Saltstone. The concentrated shurry will be transferred for vitrification in DWPF.

Fissile isotopes of uranium are contained in the high-level nuclear waste (HLW) that will be processed for permanent disposal via the ITP and sludge processing processes. ${ }^{1}$ An understanding of the distribution of uranium between supernatant liquid, alkaline solids (saltcake), and sludge is required by High-Level Waste Engineering (HLWE) to develop. a material balance for Tank Farm processing operations. This information is necessary to address nuclear criticality safety concerns. Two concerns are that fissile uranium, contained in the saltcake, will either not dissolve during salt dissolution or will dissolve at a much slower rate than saltcake. Either mechanism could result in uranium settling in the tank and collecting in sufficient quantity to form a critical mass. The solubility of uranium in alkaline salt solutions has been measured to better understand the behavior of the fissile material. ${ }^{2,3}$ The objective of this experimental program was to investigate uranium distribution and dissolution behavior in hopes of providing guidance for safe dissolution and removal of saltcake from Tank $41 \mathrm{H}$.

\section{EXPERIMENTAL PROCEDURE}

\section{Simulated Waste Solutions}

Simulated supernate wastes with typical H-Area Modified Purex (HM) low-heat and post-aluminum dissolution compositions, both spiked with depleted uranium, were used in the evaporation studies. The low-heat waste composition is based upon analytical data from supernate and saltcake samples from a January 1981 waste inventory estimate: ${ }^{4}$ The post-aluminum dissolution waste composition is based on analysis of decanted supernate from an evaporator feed tank, $43 \mathrm{H}$, during an in-tank sludge processing demonstration in 1983.5 The nominal and measured compositions of the simulated test solutions are shown in Table I and Table II.

Aluminum nitrate, $\mathrm{Al}\left(\mathrm{NO}_{3}\right)_{3} \cdot 9 \mathrm{H}_{2} \mathrm{O}$, was dissolved separately with excess sodium 
hydroxide, $\mathrm{NaOH}$, in distilled water to form sodium aluminate, $\mathrm{NaAlO}_{2}$, for the low-heat waste. Because of the lower nitrate level in the post-aluminum dissolution waste, a 65 wt $\% \mathrm{NaAlO}_{2} / 19$ wt \% NaOH reagent was used instead of aluminum nitrate. For both simulants, the remaining components were mixed with distilled water and the aluminate solutions were added slowly while stirring. A $250 \mathrm{~g} \mathrm{U} / \mathrm{L}$ solution was prepared with depleted uranyl nitrate $\left(\mathrm{UO}_{2}\left(\mathrm{NO}_{3}\right)_{2} \cdot 6 \mathrm{H}_{2} \mathrm{O}\right)$ in $0.1 \mathrm{M}$ nitric acid. This. uranium solution was added to the waste simulants at a concentration of $100 \mathrm{mg} U / \mathrm{L}$ solution. The solutions were then allowed. to stir for one week. After stirring, the solutions were filtered with a $0.45 \mu \mathrm{m}$ filter to remove insoluble uranium solids.

\section{Evaporation Runs}

The starting solution volume for the evaporation tests was approximately four liters. The starting solution densities of the low-heat waste and post-aluminum dissolution waste were 1.29 and $1.24 \mathrm{~g} / \mathrm{cm}^{3}$, respectively. Successive batch evaporations were performed on the waste simulants until the density of the supernate was approximately $1.5 \mathrm{~g} / \mathrm{cm}^{3}$.

The evaporations were performed in a $6 \mathrm{~L} \mathrm{Teflon"} \mathrm{vessel} \mathrm{heated} \mathrm{by} \mathrm{resistance-heated}$ Chromalox ${ }^{n}$ elements. Figure 1 is a schematic of the evaporator setup. The solutions were heated to boiling and the overhead vapors were condensed and collected in a beaker. The volume of water removed for each evaporation step was based upon the estimated amount of evaporation required to obtain a solution density of $1.5 \mathrm{~g} / \mathrm{cm}^{3}$. Once the desired volume of water was evaporated, the. boiling solution was removed from the evaporator and coliected in a volumetric flask. Three $15.30 \mathrm{~mL}$ samples of the boiling solution were also collected in test tubes for analysis. These solutions were cooled to room temperature to allow crystallization of sodium salts. The supernate in the volumetric flask was decanted from the solids (saltcake) and the supernate solution density was determined. If the density was less than $1.5 \mathrm{~g} / \mathrm{cm}^{3}$, the decanted supernate was returned to the evaporator as the feed solution for the next evaporation step. This evaporation and precipitation procedure was repeated until the resulting supernate density was approximately $1.5 \mathrm{~g} / \mathrm{cm}^{3}$. A flowchart for the evaporation process is shown in Figure 2.

\section{Sample Analysis -}

The $15-30 \mathrm{~mL}$ supernate/solid samples from each evaporation step were analyzed to determine the volume, weight, and chemical composition of supernate and saltcake. The supernate from each sample-was decanted and the saltcakes were centrifuged to remove interstitial liquid. Any interstitial liquid collected during centrifuging was added to the decanted solution. The saltcakes were centrifuged at $2200 \mathrm{rpm}$ in approximately thirty minute intervals until no liquid was observed. Centrifuging times ranged from thirty minutes to approximately two hours. Volume and weight measurements were made on the supernate and saltcake. Supernate volumes ranged from approximately $10-25 \mathrm{~mL}$ and saltcake weights ranged from approximately $2.5-10 \mathrm{~g}$. The supernate samples were 
analyzed for chemical composition. The saltcake from the first sample of each evaporation step was completely dissolved in $25 \mathrm{~mL}$ of distilled, deionized water and then analyzed for chemical composition. The condensed overhead solutions from the low-heat waste for each evaporation step were also analyzed for chemical composition.

\section{Saltcake Rinse Study}

The-second saltcake sample from each evaporation step was also centrifuged and then rinsed three times with 5 -mL volumes of a high concentration sodium-salt solution. The rinse solution had the following concentration:

\begin{tabular}{|c|c|c|}
\hline $\begin{array}{c}\text { Component } \\
\mathrm{NaOH} \\
\mathrm{NaNO}_{3} \\
\mathrm{NaNO}\end{array}$ & $\begin{array}{l}\text { Nominal } \\
4.50 \mathrm{M} \\
2.00 \mathrm{M} \\
1.00 \mathrm{M}\end{array}$ & $\begin{array}{c}\text { Measurec } \\
4.59 \mathrm{M} \\
1.87 \mathrm{M} \\
0.92 \mathrm{M}\end{array}$ \\
\hline
\end{tabular}

After the third rinse, the saltcake was dissolved in $25 \mathrm{~mL}$ of distilled, deionized water. The rinse solutions and dissolved saltcake solution were analyzed for uranium content. The aim of the study was to rinse the saltcake with minimal dissolution of the solids while removing uranium from any remaining interstitial liquid. However, significant salt dissolution occurred during rinsing; therefore, distinction between the uranium content of the interstitial liquid and of the saltcake could not be determined directly. Nevertheless, preliminary information on salt dissolution may be gained from this study.

\section{Sample Chemical Analysis}

Chemical analysis was performed by the Analytical Development Section. A portion of the solutions were filtered through a $0.2 \mu \mathrm{m}$ filter. Uranium analysis was performed on unfiltered and filtered solutions. Uranium was analyzed by laser-activated fluorescence ("Chemchek") and by x-ray fluorescence. Unfiltered solutions were analyzed for the remaining constituents. Concentrations of aluminum (Al), sodium ( $\mathrm{Na}$ ), silicon (Si), and phosphorous (P) were analyzed by inductively-coupled plasma (ICP) emission spectroscopy. Nitrate $\left(\mathrm{NO}_{3}{ }^{-}\right)$, nitrite $\left(\mathrm{NO}_{2}{ }^{-}\right)$, phosphate $\left(\mathrm{PO}_{4}{ }^{3}\right)$, oxalate $\left(\mathrm{C}_{2} \mathrm{O}_{4}{ }^{2-}\right)$, and sulfate $\left(\mathrm{SO}_{4}^{2}\right)$ were measured by ion chromatography. Hydroxide $\left(\mathrm{OH}^{*}\right)$, aluminate $\left(\mathrm{AlO}_{2}{ }^{-}\right)$, and carbonate $\left(\mathrm{CO}_{3}{ }^{2}\right)$ were determined from titration.

\section{RESULTS AND DISCUSSION}

An understanding of the distribution of 'uranium between supernatant liquid, alkaline solids (saltcake), and sludge is necessary to develop a material balance for Tank Farm processing operations. Concern exists that precipitated fissile uranium, contained in the saltcake, will either not dissolve during salt dissolution or will dissolve at a much slower rate than saltcake. Either mechanism could result in uranium settling in the tank and 
collecting in sufficient quantity to form a critical mass. The solubility of uranium in alkaline salt solutions has been measured to better understand the behavior of the material..$^{23}$ In this study, uranium distribution and dissolution behavior were investigated in hopes of providing guidance for safe dissolution and removal of saltcake from Tank 41H. These data are discussed in the following sections.

Superinate and Saltcake Data

\section{Low-Heat Waste Evaporation Data}

Table III lists the evaporation data for the simulated low-heat waste. Four successive evaporations were performed on the low-heat waste which increased the solution density from $1.29 \mathrm{~g} / \mathrm{cm}^{3}$ to $1.44 \mathrm{~g} / \mathrm{cm}^{3}$. The boiling point of the starting solution was $106.3^{\circ} \mathrm{C}$ while the boiling point of the supernate feed in the fourth evaporation was $117.9^{\circ} \mathrm{C}$. The total volume reduction for the low-heat waste was approximately $70 \%$ based upon the supernate remaining after the fourth evaporation plus the total volume of solids from each evaporation. The solution volume was reduced by $87 \%$. No solids crystallized from solution after the first evaporation, but solids did crystallize from solution in the remaining evaporations. The density of saltcake from each successive evaporation increased from $1.74 \mathrm{~g} / \mathrm{cm}^{3}$ to $1.86 \mathrm{~g} / \mathrm{cm}^{3}$. The weight percent interstitial liquid in saltcake was determined from the volume of liquid removed from saltcake during centrifuging. The amount of interstitial liquid in saltcake was $14 \mathrm{wt} \%$ after the second and third evaporations and $18 \mathrm{wt} \%$ after the fourth evaporation. (Appendix A describes the calculations used to determine the data in Table III.)

\section{Low-Heat Waste Supernate}

Table IV provides the composition of the starting solution and the supernate solutions after each evaporation step for the low-heat waste. Chemical analysis was performed on decanted supernate plus any liquid removed during centrifuging of the saltcake. The data represent the average of two samples from each evaporation step. As shown, the hydroxide concentration increased with each evaporation from $1.22 \mathrm{M}$ in the starting solution to $5.22 \mathrm{M}$ after the fourth evaporation. Nitrate initially increased after the first evaporation and thendecreased with each evaporation. Nitrite and aluminate increased with each evaporation. Uranium increased from $8.1 \mathrm{mg} / \mathrm{L}$ to $31.4 \mathrm{mg} / \mathrm{L}$.

The solution concentrations for the major components of the low-heat waste, as a function of hydroxide concentration, are shown graphically in Figures 3-6. Data from a previous uranium solubility study performed by D.G. Karraker ${ }^{3}$ and data from the postaluminum dissolution waste are also shown in the figures. As indicated in Figures 3-5, the solutions studied by Karraker behaved similarly to the low-heat waste used in the present study; however, the low heat waste had slightly higher nitrate concentrations and slightly lower nitrite concentrations as compared to the Karraker data. 
The uranium concentrations as a function of hydroxide are shown in Figure 6. The uranium concentrations are significantly lower at the 1-2 M hydroxide concentrations in the low-heat waste as compared to the Karraker data which indicates that the low-heat waste was not saturated with uranium in the starting solution. However, the uranium concentrations in the 3-6 M hydroxide range are slightly higher than the Karraker data. The data suggest that uranium solubility may be significantly affected by concentrations of other components of the waste. In addition, as discussed by Karraker, ${ }^{3}$ measurements of the solubility of $U$ in strongly basic solutions can depend greatly on the method used for solution make-up. The data from the low-heat waste study are currently being compared with a uranium solubility model as a function of the major waste components developed by D.T. Hobbs. ${ }^{2}$ This comparison will be reported in a summary report of all previous uranium solubility studies.

\section{Low-Heat Waste Saltcake}

Saltcake was not produced during the first evaporation step because the waste components of the low-heat waste had not reached their solubility limits. Saltcake was produced after the second, third, and fourth evaporations. Tables V and VI show the composition of saltcake after each evaporation step. Chemical analysis was performed on centrifuged saltcake samples completely dissolved in distilled, deionized water. The weight percents in Table $\mathrm{V}$ are based on the total weight of the common sodium salts associated with each ion. The weight percents in Table VI are based on the total saltcake weight which includes the sodium salts plus water. Weight percent water was calculated from the difference between the weight of the sodium compounds and the total weight of saltcake. The calculated weight percent water is asşumed to be fairly accurate because the total sodium moles calculated from the common sodium compounds associated with each ion were nearly equal to the sodium moles analyzed by inductively-coupled plasma emission spectroscopy as shown in Table VI.

As shown in Table $V$, the concentration of major components remain fairly constant for each evaporation while the weight of solids from each evaporation decreases with each succeeding step. The major component by weight is nitrate $(\sim 80 \mathrm{wt} \%$ based on total sodium salt weight for each evaporation). The weight percent undissolved uranium and dissolved uranium in fnterstitial liquid remaining after centrifuging for each evaporation is approximately $0.0011 \%$. The weight percent water in saltcake decreased from 27 and $24 \%$ after the second and third evaporations to $8 \%$ after the fourth evaporation.

\section{Low-Heat Waste Overheads Composition}

Table VIl shows the chemical analysis of the condensed overhead vapors from each evaporation step of the low-heat waste. Uranium was not detected in any of the condensate. No significant amounts of other major components were observed in these solutions. 


\section{Past-aluminum Dissolution Waste Evaporation Data}

Table VIII shows the evaporation data for the simulated post-aluminum dissolution waste. Three successive evaporations were performed on the post-aluminum dissolution waste which increased the solution density from $1.24 \mathrm{~g} / \mathrm{cm}^{3}$ to $1.47 \mathrm{~g} / \mathrm{cm}^{3}$. The boiling point of the starting solution was $104.3^{\circ} \mathrm{C}$ and the boiling point of the supernate feed in the third evaporation was $122.5^{\circ} \mathrm{C}$. The total volume reduction for the post-aluminum dissolution waste was approximately $69 \%$ based upon the supernate remaining after the third evaporation plus the total volume of solids from each evaporation. The solution volume was reduced by $80 \%$. Solids crystallized from solution after each evaporation step and the saltcake density increased from $1.41 \mathrm{~g} / \mathrm{cm}^{3}$ to $1.76 \mathrm{~g} / \mathrm{cm}^{3}$. The concentration of interstitial liquid in saltcake determined from centrifuging was 6 wt \% after the first evaporation and approximately $20 \mathrm{wt} \%$ after the second and third evaporations. (Appendix A describes the calculations used to determine the data in Table VIII.)

\section{Past-aluminum Dissolution Waste Supemate}

Table IX shows the composition of the starting solution and the supernate solutions after each evaporatinn step for the post-aluminum dissolution waste. Chemical analysis was performed on decanted supernate plus any liquid removed during centrifuging of the saltcake. The data represent the average of two samples from each evaporation step. As shown, the hydroxide concentration increased with each evaporation from $2.75 \mathrm{M}$ in the starting solution to $8.80 \mathrm{M}$ after the third evaporation. Nitrate initially increased after the first evaporation and then decreased with each evaporation. Nitrite and aluminate increased with each evaporation. Uranium concentration was initially $45.0 \mathrm{mg} / \mathrm{L}$ and then decreased and remained constant at approximately $20 \mathrm{mg} / \mathrm{L}$.

The solution concentrations for the major components of the post-aluminum dissolution waste as a function of hydroxide concentration are shown graphically in Figures 3-6 along with data from the low-heat waste and data from Karraker. ${ }^{3}$ As indicated in Figures 4 and 5 the concentrations of $\mathrm{NO}_{2}^{-}$and $\mathrm{AlO}_{2}^{-}$as a function of hydroxide in the postaluminum dissolution waste are significantly lower than the low-heat waste and the Karraker data. The uranium concentrations (Figure 6), as a function of hydroxide, are comparable to the Karraker data at the low hydroxide range but slightly higher in the 5-9 $\mathrm{M}$ hydroxide range. This suggests that the uranium solubility is strongly dependent on hydroxide concentration but may also be affected by concentrations of other components. The data from the post-aluminum dissolution waste are also currently being compared with a uranium solubility model as a function of waste components developed by Hobbs. ${ }^{2}$ This comparison will be reported in a summary report of all previous uranium solubility studies. 


\section{Past-aluminum Dissolution Waste Saltcake}

Saltcake was produced during each evaporation step for the post-aluminum dissolution waste. Tables $\mathrm{X}$ and $\mathrm{XI}$ show the composition of saltcake after each evaporation step. Chemical analysis was performed on centrifuged saltcake samples completely dissolved in distilled, deionized water. The weight percents in Table $\mathrm{X}$ are based on the total weight of the common sodium salts associated with each ion. The weight percents in Table XI are based on the total saltcake weight which includes the sodium salts plus water. Weight percent water was calculated from the difference between the weight of the sodium compounds and the total weight of saltcake. The calculated water content is assumed to be fairly accurate because the total sodium moles calculated from the common sodium salts associated with each ion were essentially equal to the sodium moles analyzed by inductively-coupled plasma emission spectroscopy as shown in Table XI.

As shown in Table $\mathrm{X}$, as in the case of the low-heat waste, the major component is nitrate $(-60 \mathrm{wt} \%$ based on total sodium salt weight for post-aluminum vs. $-80 \mathrm{wt} \%$ for low-heat). The concentration of undissolved uranium and dissolved uranium in interstitial liquid decreases îrom $0.0073 \mathrm{wt} \%$ to $0.0057 \mathrm{wt} \%$. The amount of water in saltcake increases from $23 \mathrm{wt} \%$ after the first evaporation to $37 \mathrm{wt} \%$ after the third evaporation.

\section{Uranium Distribution During Evaporation}

\section{Low-Heat Waste}

Low-heat waste was subjected to four successive evaporations. Saltcake was produced from each of the last three evaporations. :The incremental percentage of uranium contained in the saltcake (i.e., undissolved uranium and dissolved uranium contained in interstitial liquid) decreased with each successive evaporation. For low-heat waste, the fraction of total uranium contained in saltcake is 22,18 , and $8 \mathrm{wt} \%$ for the second, third, and fourth evaporations, respectively (as shown in Table XII). The cause of this observation is likely the result of a combination of two factors. First, each successive evaporation produces less saltcake than the previous one. This results in a decrease in the amount of interstitial liquid. Second, the uranium concentration in the supernate is increasing. This would indicate that the uranium solubility limit has not been reached. Therefore, the ratio of uranium contained in the saltcake to uranium in solution is decreasing. Simply stated, the salts (i.e., $\mathrm{NaOH}, \mathrm{NaNO}_{3}, \mathrm{NaNO}_{2}$, etc.) in this particular solution have reached their solubility limit for the second, third, and fourth evaporations while the uranium has either not reached, or has just reached, its solubility limit by the fourth evaporation. This theory suggests that the majority of uranium contained in saltcake produced by the second and third evaporations is present in interstitial liquid. The effect of the four evaporation cycles, as a whole, on the low-heat.waste is that $42 \%$ of the uranium is contained in the composite saltcake. An estimate of the amount of . 
dissolved uranium contained in interstitial liquid is discussed in a later section (Estimate of Dissolved Uranium in Interstitial Saltcake Liquid).

\section{Post-Aluminum Dissolution Waste}

Similar to the observations with low-heat waste, the incremental percentage of uranium contained in saltcake from evaporation of post-aluminum dissolufion waste decreases with each successive evaporation. For post-aluminum dissolution waste, the fraction of total uranium contained in saltcake is 49,22 , and $19 \mathrm{wt} \%$ for the first, second, and third evaporations, respectively (as shown in Table XIII). These percentages (specifically that for the first evaporation) are higher than those observed for the low-heat waste. This is expected in light of the fact that the post-aluminum dissolution waste starting solution had a uranium concentration of $45.0 \mathrm{mg} / \mathrm{L}$ and that $78 \%$ of the uranium was contained in solids larger than $0.2 \mu \mathrm{m}$. The large size would suggest that the uranium was colloidal and would easily separate from solution. Therefore; the first evaporation likely caused a large portion of the uranium to aggregate with the saltcake. A similar pattern was repeated for the second evaporation; however, a much smaller percentage of the uranium was contained in solids larger than $0.2 \mu \mathrm{m}$ (Table IX). The effect of the three évaporation cycles, as a whole, on the post-aluminum dissolution waste is that $68 \%$ of the uranium is contained in the composite saltcake. An estimate of the amount of dissolved uranium contained in interstitial liquid is discussed in a later section (Estimate of Dissolved Uranium in Interstitial Saltcake Liquid).

\section{Uranium Dissolution}

\section{Low-Heat Waste}

Analysis of the data from the rinse of low-heat waste saltcake indicates that the first rinse of saltcake with concentrated alkaline solution results in the removal (either from. undissolved uranium or from dissolved uranium contained in interstitial liquid) of the greatest percentage of uranium (i.e., 34 to $45 \%$ uranium dissolution). This is true for saltcake produced from all three evaporations. Second and third rinses of saltcake achieved 18 to $25 \%$ uranium dissolution for all evaporated saltcake. Dissolution of the remaining saltcake showed that approximately 4 to $16 \%$ of the uranium remained in the saltcake after three rinses. Data from the rinse tests are contained in Table XIV.

One important aspect of the rinsing behavior, which is applicable to Tank $41 \mathrm{H}$ processing, was the determination of the relative rate of uranium dissolution as compared to salt dissolution. Relevant data is listed in Table XIV and shown graphically in Figure 7. Throughout the rinse tests, the ratio of uranium removed by rinsing to saltcake dissolved was greater than 1.0. This implies that uranium is removed from the saltcake at a faster rate than saltcake. is dissolved. However, this data is not directly applicable to planned Tank $41 \mathrm{H}$ operations. Since the objective of rinse testing was to quantify the amount of dissolved uranium contained in interstitial liquid in the saltcake, 
Page 10

WSRC-RP-94-251

a 7.5 $\mathrm{M} \mathrm{Na}^{+}$solution was used for the rinse so that salt dissolution would be minimized.

\section{Past-Aluminum Dissolution Waste}

The rinse tests of post-aluminum dissolution waste saltcake offer similar observations to those for low-heat waste. The first rinse of saltcake resulted in the removal of the greatest percentage of uranium (i.e., 48 to $54 \%$ uranium dissolution) from saltcake produced from the three evaporations. A second rinse of the saltcake achieved 23 to $30 \%$ uranium dissolution for evaporated saltcake. A third rinse of the saltcake achieved 12 to $15 \%$ uranium dissolution for evaporated saltcake. Dissolution of the remainder of the saltcake remaining after three rinses showed that approximately 5 to $14 \%$ of the uranium remained in the saltcake after rinsing. Data from these rinse tests are contained in Table XV.

Analysis of the relative rates of uranium and salt dissolution indicate similar trends to those observed for low-heat waste. Data is listed in Table XV and shown graphically in Figure 8. Once again, the ratio of total uranium removed by rinsing to total saltcake dissolved was greater than 1.0 thropghout the testing. Again, this data is not directly applicable to Tank $41 \mathrm{H}$ operations since the objective of the rinse testing was to inhibit salt dissolution so as to quantify the amount of dissolved uranium contained in interstitial liquid within the saltcake.

\section{Uranium Size Distribution}

\section{Low-Heat Waste}

The percentage of uranium contained in solids larger than $0.2 \mu \mathrm{m}$ was determined for supernate and saltcake rinse samples. Analysis indicates that, within experimental error, most, if not all, of the uranium which remained in the supernate was either dissolved or contained in solids significantly smaller than $0.2 \mu \mathrm{m}$ (see Table IV). Only supernate after four evaporations was observed to show any observable quantity (8\%) of uranium that was contained in solids larger than $0.2 \mu \mathrm{m}$. Hence it appears that the solubility limit for uranium was not reached until the last evaporation cycle.

Analysis of the saltcake rinse data showed two trends with regards to the size of uranium-containing solids (see Table XIV). First, the percentage of uranium that was contained in solids larger than $0.2 \mu \mathrm{m}$, obtained by rinsing and dissolving saltcake, increased with each rinse. Second, the observed uranium behavior in the saltcake from the second and third evaporations is approximately the same. However, almost all of the uranium from saltcake produced by the fourth evaporation was shown to be either dissolved or contained in solids significantly smaller than $0.2 \mu \mathrm{m}$. As a whole, $67 \%$ of the uranium in saltcake from the second evaporation was either dissolved or contained in solids smaller than $0.2 \mu \mathrm{m}$ in size. The third evaporation resulted in $73 \%$ of the uranium being either dissolved or containned in solids smaller than $0.2 \mu \mathrm{m}$. Greater than $98 \%$ of 
the uranium obtained from saltcake from the fourth evaporation was either dissolved or contained in solids smaller than $0.2 \mu \mathrm{m}$.

\section{Post-Aluminum Dissolution Waste}

As noted earlier, analysis of post-aluminum dissolution supernate data shows that $22 \%$ of the uranium is either dissolved or contained in solids significantly smaller than $0.2 \mu \mathrm{m}$. Similar analysis of the supernate after the three evaporations indicate that the vast majority ( 81 to $97 \%$ ) of the uranium is either dissolved or contained in solids smaller than $0.2 \mu \mathrm{m}$. Data are contained in Table IX.

The trend of the data collected from the rinses of post-aluminum dissolution waste saltcake is opposite of that observed for low-heat waste saltcake (see Table XV). In general, the percentage of uranium that was either dissolved or contained in solids smaller than $0.2 \mu \mathrm{m}$, obtained by rinsing and dissolving saltcake, increased with each rinse. The residual saltcake dissolved in water contained substantially lesser quantities of either dissolved uranium or uranium-containing solids smaller than $0.2 \mu \mathrm{m}$. Additionally, an increase in the percentage that was either dissolved or contained in solids smaller than $0.2 \mu \mathrm{m}$ was observed for the second evaporation cycle. However, the third evaporation cycle formed saltcake that contained either dissolved uranium or uranium-containing solids smaller than $0.2 \mu \mathrm{m}$ size in substantially lower percentages. As a whole, $25 \%$ of the uranium in saltcake from the first evaporation was either dissolved or contained in solids smaller than $0.2 \mu \mathrm{m}$ in size. The second evaporation resulted in $88 \%$ of the uranium being either.dissolved or contained in solids smaller than $0.2 \mu \mathrm{m}$. Lastly, $34 \%$ of the uranium obtained from saltcake from the third evaporation was either dissolved or contained in solids significantly smaller than $0.2 \mu \mathrm{m}$. The cause of this discrepancy (in comparison to Low-Heat waste) bas not been determined.

\section{Estimate of Dissolved Uranium in Interstitial Saltcake Liquid}

\section{Low-Heat Waste}

The amount of dissolved and undissolved uranium contained in the interstitial liquid of the saltcake was estimtated from the experimental data. The estimate was obtained from the weight percene water contained in a saltcake sample and the composition of the supernate above the saltcake. From this data, the volume of supernate remaining in the saltcake after centrifuging was determined. Using the uranium concentration of the supernate and the volume of supernate remaining in the saltcake, it was possible to estimate the quantity of dissolved uranium that is present in the saltcake. The difference between the measured total uranium contained in the saltcake and the dissolved uranium is undissolved uranium. Using this method, it was estimated that 82,100 , and $16 \mathrm{wt} \%$ of the uranium contained in the saltcake from the second, third, and fourth evaporations, respectively, of low-heat waste was dissolved. Data presented in the Uranium Distribution During Evaporation section of this document showed the fraction of total 
uranium contained in the saltcake from the second, third, and fourth evaporations of low-heat waste was 22,18 and $8 \mathrm{wt} \%$, respectively. Coupling this data with the above estimates would predict that the fraction of total uranium present as undissolved uranium in saltcake from the second, third, and fourth evaporations of low-heat waste is 4.0, 0.0 and $6.7 \mathrm{wt} \%$, respectively. The effect of the four evaporation cycles, as a whole, on the low-heat waste is that an estimated $10 \%$ of the total uranium originally present in the salt solution is precipitated as a solid.

The fact that this value is relatively low is not unexpected. Three pieces of evidence support this estimate. First, rinse data presented earlier in this document showed that 84 to $96 \%$ of the uranium contained in the low-heat saltcake from the three evaporations was removed by rinsing. Second, documented information shows that precipitated uranium does not readily dissolve in highly caustic salt solutions. ${ }^{2,3}$ Third, the percentage of uranium contained in the salt solution rinses that was less than $0.2 \mu \mathrm{m}$ in size was relatively large (i,e., a 67 to $98 \%$ range for the second, third, and fourth evaporations). Coupling these three pieces of evidence suggest that a large fraction of the uranium contained in the centrifuged, low-heat waste saltcake samples was in fact uranium dissolved in the interstitial liquid.

\section{Post-Alumirum Dissolution Waste}

The amount of dissolved uranium contained in the interstitial liquid of saltcake was estimated for post-aluminum dissolution waste. Using the method described above, it was estimated that 14,79 , and 32 wt $\%$ of the uranium contained in the saltcake from the first, second, and third evaporations, respectively, of post-aluminum dissolution waste was dissolved. Data presented in the Uranium Distribution During Evaporation section of this document showed the fraction of total uranium contained in the saltcake from the first, second, and third evaporations of post-aluminum dissolution waste was 49, 22 and $19 \mathrm{wt} \%$, respectively. Coupling this data with the above estimates would project that the fraction of total uranium present as undissolved uranium in saltcake from the first, second, and third evaporations of post-aluminum dissolution waste is $42,4.6$ and $13 \mathrm{wt} \%$, respectively. The effect of the three evaporation cycles, as a whole, on the post-aluminum dissolution waste is that an estimated $52 \%$ of the total uranium originally present in the salt solution is precipitated as a solid.

This value shows.that a substantial portion of the uranium is present in a solid phase. This appears to contradict the rinse data presented earlier. The rinse data showed that 86 to $95 \%$ of the uranium contained in the post-aluminum dissolution waste saltcake from the three evaporations was removed by rinsing. However, the percentage of uranium contained in the salt solution rinses that was less than $0.2 \mu \mathrm{m}$ in size varied widely (i.e., a 25 to $88 \%$ range for the first, second, and third evaporations). Again, documented information shows that precipitated uranium does not readily dissolve in highly caustic salt solutions. 2,3 Therefore, the evidence supports the theory that the undissolved uranium was not "trapped" or bound to the saltcake mass (i.e., the 
undissolved uranium was either "free" or attached to small saltcake fragments).

\section{FUTURE WORK}

As discussed earlier, the high alkaline rinse solutions used in the current study were designed to rinse saltcake and minimize salt dissolution. Significant salt dissolution occurred, however, during rinsing. Salt dissolution in Tank $41 \mathrm{H}$ will most likely be performed with much lower hydroxide concentrations; therefore, the salt dissolution data obtained from the current rinse study is not directly applicable to Tank 41H. Additional dissolution studies are in progress for these salts that are directly applicable to Tank $41 \mathrm{H}$.

\section{QUALTTY ASSURANCE}

All work was performed at the request of HLWE (HLWE-TTR-93-001) and conducted in accordance with the DWP\&HT Quality Assurance Procedures Manual, 1043. The experimental work was conducted in accordance with Task Technical Plan WSRC-RP-93-80 and Task Quality Assurance Plan WSRC-RP-93-79.6,7 Data from evaporation runs were kept in laboratory notebook WSRC-NB-90-297 and WSRC-NB93-45. Chemical analyses were performed by the Analytical Development Section.

\section{REFERENCES}

1. W. S. Cavin, "Separations Waste Sludge Spreadsheet (U)," WSRC-TR-93-135, Revision 1, July 29, 1993.

2. D. T. Hobbs, T. B. Edwards, and S. D. Fleischman, "Solubility of Plutonium and Uranium in Alkaline Salt Solutions (U)," WSRC-TR-93-056, February 12, 1993.

3. D. G. Karraker, "Uranium Solubility Studies During Waste Evaporation (U)," WSRC-TR-93-433, Revision 0, August 16, 1993.

4. J.R. Fowler, "Composition of H Area and SRP Soluble High-level Waste," DPST82-502, April 28, 1982.

5. R.E. Eibling and B.A. Hamm, "Demonstration of In-tank Sludge Processing, Part IV: Decanted Supernate Composition," DPST-84-798, October 2, 1984.

6. M. J. Barnes, "Task Technical Plan for Salt Dissolution Studies (U)," WSRC-RP-93-80, January 11, 1993.

7. M. J. Barnes, "Task Quality Assurance Plan for Salt Dissolution Studies (U)," WSRC-RP-93-80, January 7, 1993. 


\section{TABLE I} Simulated Low-heat Waste Composition

Component

$\mathrm{NaNO}_{3}$

$\mathrm{NaNO}_{2}$

$\mathrm{NaOH}$

$\mathrm{Na}_{2} \mathrm{CO}_{3}$

$\mathrm{NaAlO}_{2}$

$\mathrm{Na}_{2} \mathrm{SO}_{4}$

$\mathrm{NaF}$

$\mathrm{NaCl}$

$\mathrm{Na}_{2} \mathrm{SiO}_{3}$

$\mathrm{Na}_{2} \mathrm{C}_{2} \mathrm{O}_{4}$

$\mathrm{Na}_{3} \mathrm{PO}_{4}$

Depleted Uranium
Nominal Molar
Concentration $(M)^{*}$

2.62

0.58

1.21

0.06

0.34

0.06

0.008

0.009

0.005

0.005

0.004
Measured Molar

Concentration (M)

2.44

0.53

, 1.22

0.09

0.33

0.06

0.001

0.011

0.002

0.005

0.0043

$8.1(\mathrm{mg} / \mathrm{L})$

TABLE II

Simulated Post-aluminium Dissolution Waste Composition

\begin{tabular}{|c|c|c|}
\hline Component & $\begin{array}{c}\text { Nominal Molar } \\
\text { Concentration }(M)^{*}\end{array}$ & $\begin{array}{l}\text { Measured Molar } \\
\text { Concentration (M) }\end{array}$ \\
\hline $\mathrm{NaNO}_{3}$ & 1.35 & 1.32 \\
\hline $\mathrm{NaNO}_{2}$ & 0.29 & 0.29 \\
\hline $\mathrm{NaOH}^{2}$ & 3.01 & 2.75 \\
\hline $\mathrm{Na}_{2} \mathrm{CO}_{3}$ & 0.15 & 0.22 \\
\hline $\mathrm{NaAlO}_{2}$ & 0.61 & 0.63 \\
\hline $\mathrm{Na}_{2} \mathrm{SO}_{4}$ & 0.05 & 0.05 \\
\hline $\mathrm{Na}_{2} \mathrm{SiO}_{3}$ & 0.001 & 0.002 \\
\hline $\mathrm{Na}_{2} \mathrm{C}_{2} \mathrm{O}_{4}$ & $0.003^{\cdots *}$ & 0.005 \\
\hline $\mathrm{Na}_{3} \mathrm{PO}$ & $0.002^{\circ 0}$ & 0.0043 \\
\hline Depletęd Ûranium & - & $45.0(\mathrm{mg} / \mathrm{L})$ \\
\hline
\end{tabular}

- Nominal composition from estimated composition of H-Area soluble high-level waste (Reference 4)

- Nominal composition from analysis of decanted supernate from evaporator feed tank, $43 \mathrm{H}$, during intank sludge processing demonstration (Reference 5)

*** Not found in reference 2 - estimated by keeping the concentration with respect to nitrate the same as in the low-heat waste 


\section{TABLE III \\ Low-Heat Waste Evaporation Data}

\begin{tabular}{|c|c|c|c|c|c|c|}
\hline & $\begin{array}{c}\text { vol \% } \\
\text { evaporated }\end{array}$ & $\begin{array}{l}\text { vol \% feed } \\
\text { reduced }\end{array}$ & $\begin{array}{l}\text { Cumulatwe } \\
\text { yol \& reduced }\end{array}$ & $\begin{array}{l}\text { vol \% supemato } \\
\text { in bottoms }\end{array}$ & $\begin{array}{l}\text { Density of } \\
\text { supermate } \\
\text { (e/cmin) }\end{array}$ & $\begin{array}{l}\text { Supernate } \\
\text { boiling point } \\
\text { eC }\end{array}$ \\
\hline $\begin{array}{l}\text { Start Solution } \\
\text { 1st Evaporation } \\
\text { 2nd Evaporation } \\
\text { 3rd Evaporation } \\
\text { 4th Evaporation }\end{array}$ & $\begin{array}{l}- \\
42 \\
25 \\
22 \\
13\end{array}$ & $\begin{array}{l}-\overline{4} \\
31 \\
26 \\
19\end{array}$ & $\begin{array}{l}- \\
42 \\
\infty \\
66 \\
70\end{array}$ & $\begin{array}{r}- \\
100 \\
71 \\
78 \\
90\end{array}$ & $\begin{array}{l}1.29 \\
1.38 \\
1.35 \\
1.43 \\
1.44\end{array}$ & $\begin{array}{l}106.3 \\
112.3 \\
115.2 \\
117.9\end{array}$ \\
\hline
\end{tabular}

\begin{tabular}{|c|c|c|c|c|c|}
\hline & $\begin{array}{l}\text { vol \%o saltcake } \\
\text { in bottoms }\end{array}$ & $\begin{array}{l}\text { g saltcake / } \\
\text { L bottoms }\end{array}$ & $\begin{array}{l}\text { Density of } \\
\text { saltcake } \\
\left(\mathrm{a} / \mathrm{cm}^{3}\right)\end{array}$ & $\begin{array}{l}\text { wt \% water } \\
\text { in saltcake }\end{array}$ & $\begin{array}{c}\text { wt \% } \\
\text { Interstitial likuxd } \\
\text { in saltcake }\end{array}$ \\
\hline 1st Evaporation & 0 & 0 & - & - & $=$ \\
\hline and Evaporation & 29 & 503 & 1.74 & 27 & 14 \\
\hline 3rd Evaporation & 22 & 392. & 1.77 & 24 & 14 \\
\hline 4th Evaporation & 10 & 177 & 1.86 & 8 & 18 \\
\hline
\end{tabular}

- See Appendlx A for explanation of equations used to calculate data.

TABLE IV

Low-Heat Waste Supernate Concentrations

(Average of two samples from each evaporatlon step after centrifuging)

\begin{tabular}{|c|c|c|c|c|c|}
\hline . & $\begin{array}{l}\text { Starting } \\
\text { solution }\end{array}$ & $\begin{array}{c}\text { 1st } \\
\text { Evaporation }\end{array}$ & $\begin{array}{c}\text { 2nd } \\
\text { Evaporation }\end{array}$ & $\begin{array}{c}\text { 3rd } \\
\text { Evaporation }\end{array}$ & $\begin{array}{c}\text { 4th } \\
\text { Evaporatlon }\end{array}$ \\
\hline $\mathrm{NaOH}(\mathrm{M})$ & 1.22 & 2.08 & 3.05 & 4.28 & 5.22 \\
\hline $\mathrm{NaNO}_{3}(\mathrm{M})$ & 2.44 & 4.49 & 3.34 & 2.71 & 2.16 \\
\hline $\mathrm{NaNO}_{2}(\mathrm{M})$ & 0.53 & 0.97 & 1.38 & 1.94 & 2.29 \\
\hline $\mathrm{NaAlO}_{2}(\mathrm{M})$ & 0.33 & 0.56 & 0.76 & 1.09 & 1.33 \\
\hline $\mathrm{Na}_{2} \mathrm{CO}_{3}(\mathrm{M})$ & 0.09 & 0.15 & 0.17 & 0.22 & 0.22 \\
\hline $\mathrm{Na}_{2} \mathrm{SO}_{4}(\mathrm{M})$ & 0.056 & 0.093 & 0.089 & 0.068 & 0.042 \\
\hline $\mathrm{NaF}(M)$ & 0.0014 & 0.0043 & 0.0023 & 0.0031 & 0.0038 \\
\hline $\mathrm{NaCl}(\mathrm{M})$ & 0.0105 & 0.0156 & 0.0227 & 0.0347 & 0.0413 \\
\hline $\mathrm{Na}_{2} \mathrm{SiO}_{3}(\mathrm{M})$ & 0.0023 & 0.0030 & 0.0036 & 0.0049 & 0.0060 \\
\hline $\mathrm{Na}_{3} \mathrm{PO}_{4}(\mathrm{M})$ & 0.0043 & 0.0054 & 0.0078 & 0.0103 & 0.0103 \\
\hline $\mathrm{Na}_{2} \mathrm{C}_{2} \mathrm{O}_{4}(\mathrm{M})$ & 0.0046 & 0.0075 & 0.0092 & 0.0080 & 0.0041 \\
\hline $\mathrm{U}$ - unfitered $(\mathrm{mg} / \mathrm{L})^{\star \star}$ & 8.1 & 11.7 & 18.7 & 24.6 & 31.4 \\
\hline$U$ - filtered $(\mathrm{mg} / \mathrm{L})^{-i \hbar}$ & - & - & 19.9 & 24.5 & 28.9 \\
\hline wt $\%$ of $U<0.2 \mu \mathrm{m}$ & - & - & 100 & 100 & 92 \\
\hline
\end{tabular}


WSRC-RP-94-251

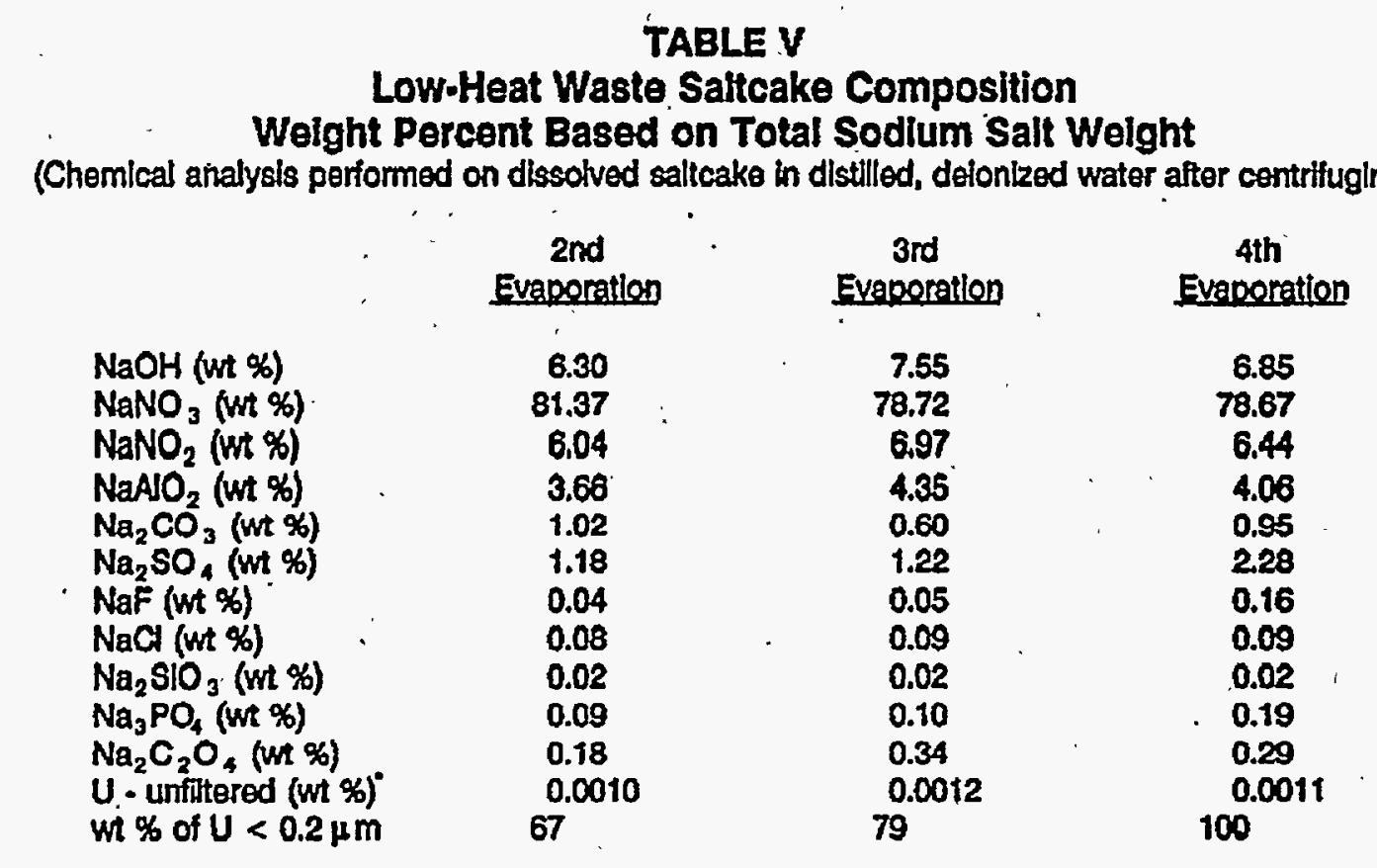

\section{TABLE VI}

Low-Heat Waste Saltcake Composition

Weight Percent Based on Total Saltcake Weight

(Chemical analysis performed on dlssolved saitcake in dlstilled, delorized water after centrifuging)

\begin{tabular}{|c|c|c|c|}
\hline & $\begin{array}{l}\text { 2nd } \\
\text { Evaporation }\end{array}$ & $\begin{array}{c}\text { 3rd } \\
\text { Evaporatlon }\end{array}$ & $\begin{array}{c}\text { 4th } \\
\text { Evaporatlon }\end{array}$ \\
\hline $\mathrm{NaOH}(w t \%)$ & 4.06 & 5.74 & 6.27 \\
\hline $\mathrm{NaNO}_{3}$ (wst \%) & 52.38 & 59.85 & 72.01 \\
\hline NaN & 3.89 & 5,30 & 5.89 \\
\hline $\mathrm{NaAO}^{2}$ (wt $\%$ ) & 2.36 & 3.31 & 3.71 \\
\hline $\mathrm{Na}_{2} \mathrm{CO}_{3}$ (wt \%) & 0.66 & 0.46 & 0.87 \\
\hline $\mathrm{Na}_{2} \mathrm{SO}_{3}$ (wt \%) & 0.76 & 0.92 & 2.09 \\
\hline $\mathrm{NaF}(\mathrm{wt} \%)$ & 0.03 & 0.04 & 0.15 \\
\hline $\mathrm{NaCl}($ (wt \%) $=$ & 0.05 & 0.07 & 0.08 \\
\hline $\mathrm{Na}_{2} \mathrm{SIO}_{3}(\mathrm{~m}+\%)$ & 0.01 & 0.01 & 0.02 \\
\hline $\mathrm{Na}_{3} \mathrm{PO}_{\text {, (wt \%) }}$ & 0.06 & 0.07 & 0.18 \\
\hline $\mathrm{Na}_{2} \mathrm{C}_{2} \mathrm{O}_{4}$ (wt \%) & 0.12 & 0.26 & 0.26 \\
\hline $\begin{array}{l}\mathrm{H}_{2} \mathrm{O}(\text { in } \%) \\
U \text { - unfitered (ut \%) }\end{array}$ & ${ }_{0.0007}^{27}$ & $\begin{array}{l}24 \\
0.0009\end{array}$ & $\begin{array}{l}8 \\
0.0010\end{array}$ \\
\hline ut $\%$ of $U<0.2 \mu \mathrm{m}$ & & & 100 \\
\hline $\begin{array}{l}\text { Sum of Na moles } \\
\text { a moles by ICP }\end{array}$ & $\begin{array}{l}0.064 \\
0.059\end{array}$ & $\begin{array}{l}0.058 \\
0.058\end{array}$ & $\begin{array}{l}0.029 \\
0.030\end{array}$ \\
\hline
\end{tabular}

- Uranlum determined by "Chemchek" analysis 
TABLE VII

Low-Heat Waste Overheads Concentrations

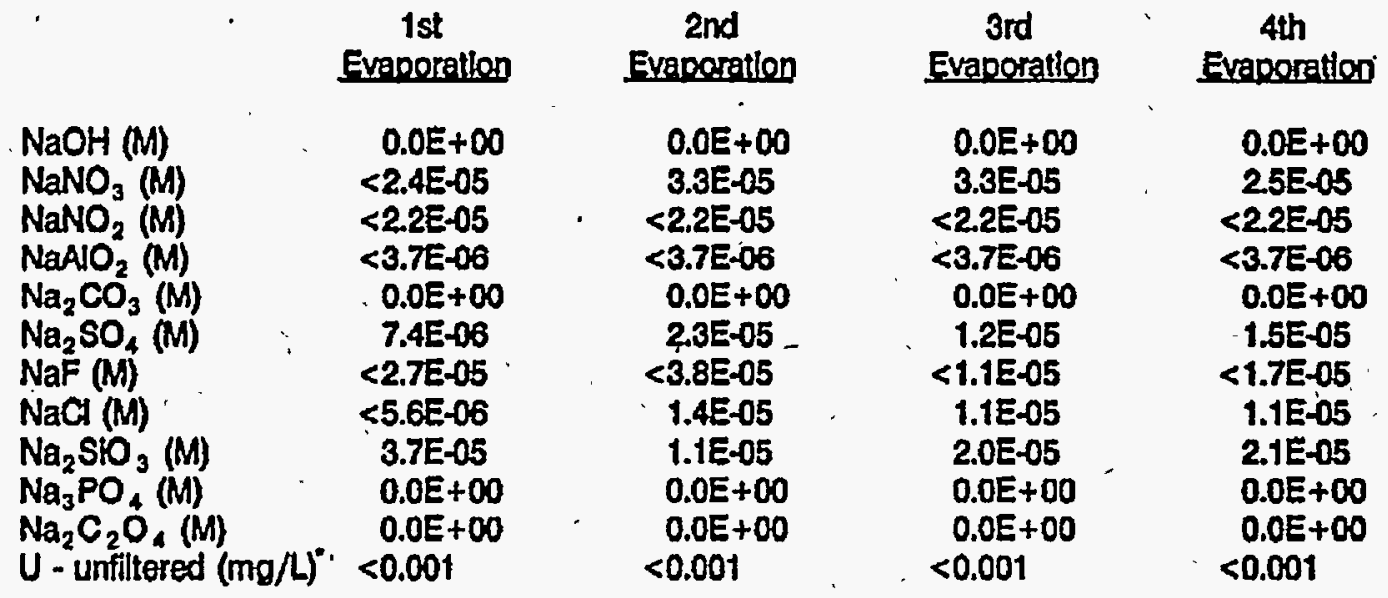

"Uranium determined by "Chemchek" analysis 
TABLE VIII •

Post-Aluminum Dissolution Waste Evaporation Data

\begin{tabular}{|c|c|c|c|c|c|c|}
\hline & $\begin{array}{c}\text { vol \% } \\
\text { evaporated }\end{array}$ & $\begin{array}{l}\text { vol \% feed } \\
\text { reduced }\end{array}$ & $\begin{array}{c}\text { Cumulative } \\
\text { yol \& rediced }\end{array}$ & $\begin{array}{l}\text { vol \% supernate } \\
\text { In bottoms }\end{array}$ & $\begin{array}{l}\text { Density of } \\
\text { supermate } \\
\text { (a/cmin) }\end{array}$ & $\begin{array}{l}\text { Supernate } \\
\text { boilling point } \\
\text { ec) }\end{array}$ \\
\hline $\begin{array}{l}\text { Start Solution } \\
\text { 1st Evaporation } \\
\text { 2nd Evaporation } \\
\text { 3rd Evaporatlon }\end{array}$ & $\begin{array}{l}-5 \\
52 \\
19 \\
11\end{array}$ & $\begin{array}{l}- \\
65 \\
25 \\
14\end{array}$ & $\begin{array}{l}- \\
55 \\
66 \\
69\end{array}$ & $\begin{array}{l}-\overline{93} \\
82 \\
89\end{array}$ & $\begin{array}{l}1.24 \\
1.41 \\
1.44 \\
1.47\end{array}$ & $\begin{array}{l}104.3 \\
117.6 \\
122.5\end{array}$ \\
\hline
\end{tabular}

\begin{tabular}{|c|c|c|c|c|c|}
\hline & $\begin{array}{l}\text { vol \% saitcake } \\
\text { in bottoms }\end{array}$ & $\begin{array}{c}\text { g saltcake / } \\
\text { L bottoms }\end{array}$ & $\begin{array}{l}\text { Density of } \\
\text { saltcake } \\
\text { (a/cmin) }\end{array}$ & $\begin{array}{l}\text { Wt \% water } \\
\text { In salteake }\end{array}$ & $\begin{array}{r}\text { Ht ? } \\
\text { interstitial } \\
\text { in saltc }\end{array}$ \\
\hline 1st Evaporation & 7 & 95 & 1.41 & 23 & \\
\hline 2nd Evaporation & 18 & 308 & 1.70 & 38 & - \\
\hline 3rd Evaporation & 11 & 191 & 1.76 & 37 & \\
\hline
\end{tabular}

- See Appendix A for explanation of equations used to calculate data

TABLE IX

Post-Aluminum Dissolution Supernate Concentrations

(Average of two samples from each evaporation step after centrifuging)

\begin{tabular}{|c|c|c|c|c|}
\hline & $\begin{array}{l}\text { Starting } \\
\text { solution }\end{array}$ & $\begin{array}{c}\text { 1st } \\
\text { Evaporation }\end{array}$ & $\begin{array}{l}\text { 2nd } \\
\text { Evaporation }\end{array}$ & $\begin{array}{c}\text { 3rd } \\
\text { Evaporation }\end{array}$ \\
\hline 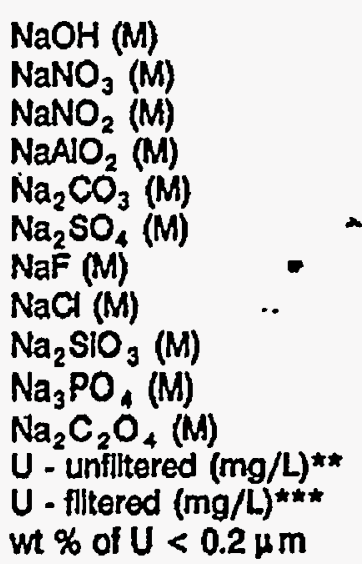 & $\begin{array}{l}2.75 \\
1.32 \\
0.29 \\
0.63 \\
0.22 \\
0.045 \\
0.0050 \\
0.0005 \\
0.0029 \\
0.0013 \\
0.0020 \\
45.0 \\
10.0 \\
22\end{array}$ & $\begin{array}{l}5.71 \\
2.38 \\
0.59 \\
1.28 \\
0.22 \\
0.043 \\
0.0033 \\
0.0005 \\
0.0058 \\
0.0043 \\
0.0045 \\
23.3 \\
18.9 \\
81\end{array}$ & $\begin{array}{l}7.27 \\
1.84 \\
0.77 \\
1.77 \\
0.11 \\
0.025 \\
0.0077 \\
0.0008 \\
0.0069 \\
0.0044 \\
0.0045 \\
23.0 \\
22.3 \\
97\end{array}$ & $\begin{array}{l}8.80 \\
1.43 \\
0.88 \\
1.93 \\
0.09 \\
0.016 \\
0.0108 \\
0.0006 \\
0.0072 \\
0.0044 \\
0.0045 \\
21.4 \\
18.5 \\
86\end{array}$ \\
\hline
\end{tabular}

- Uranlum determined from $x$-ray fluoresceneo

".." Solution filtered with a 0.2 \&m filter. 


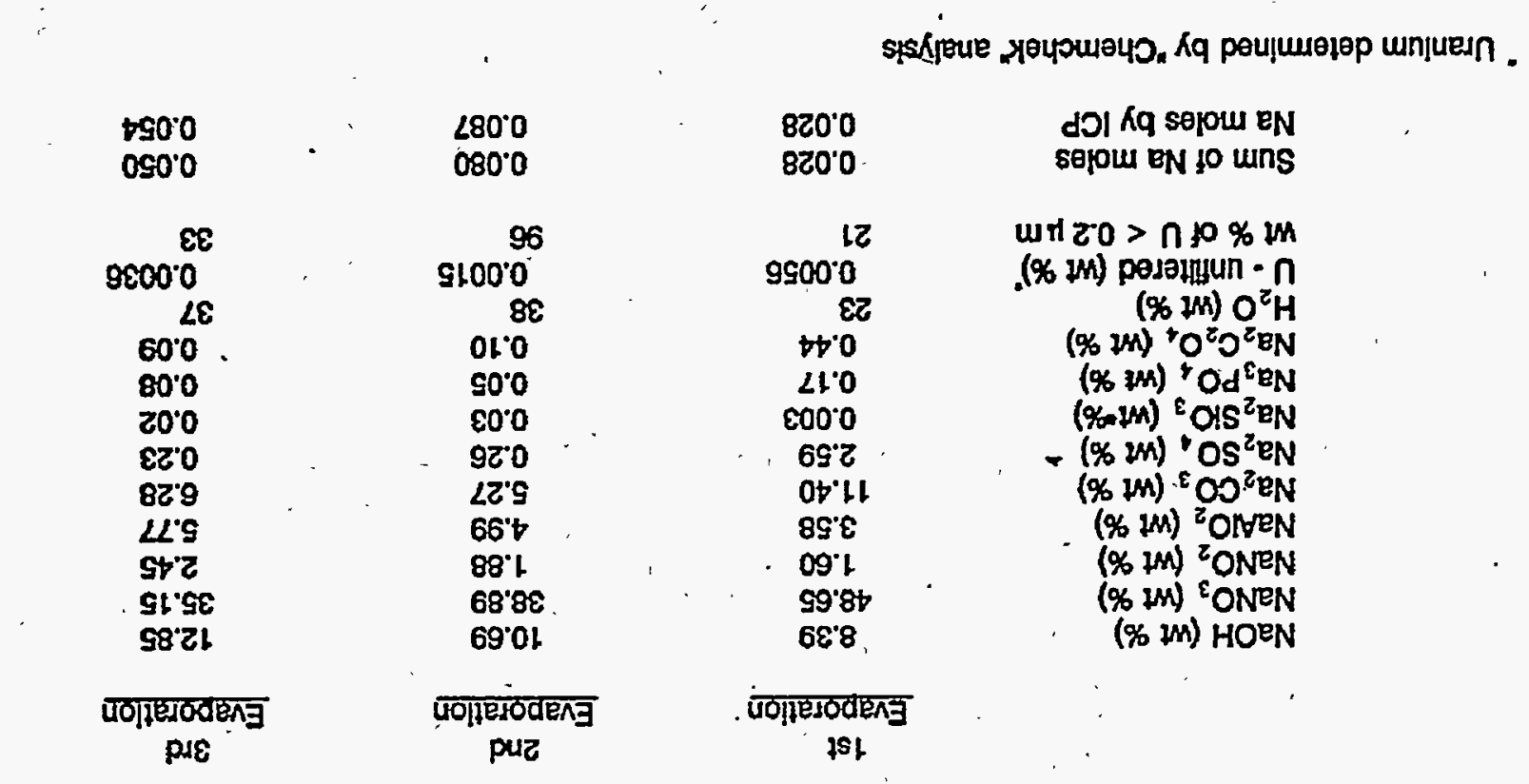

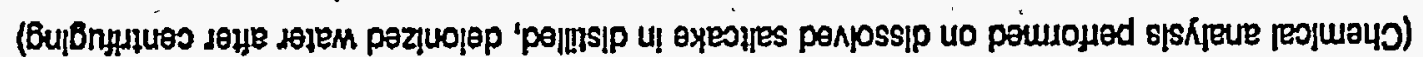

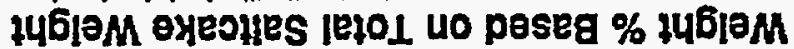

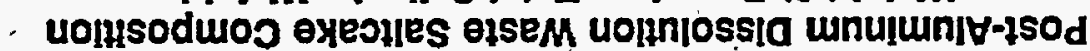

IX $\exists 78 \forall 1$

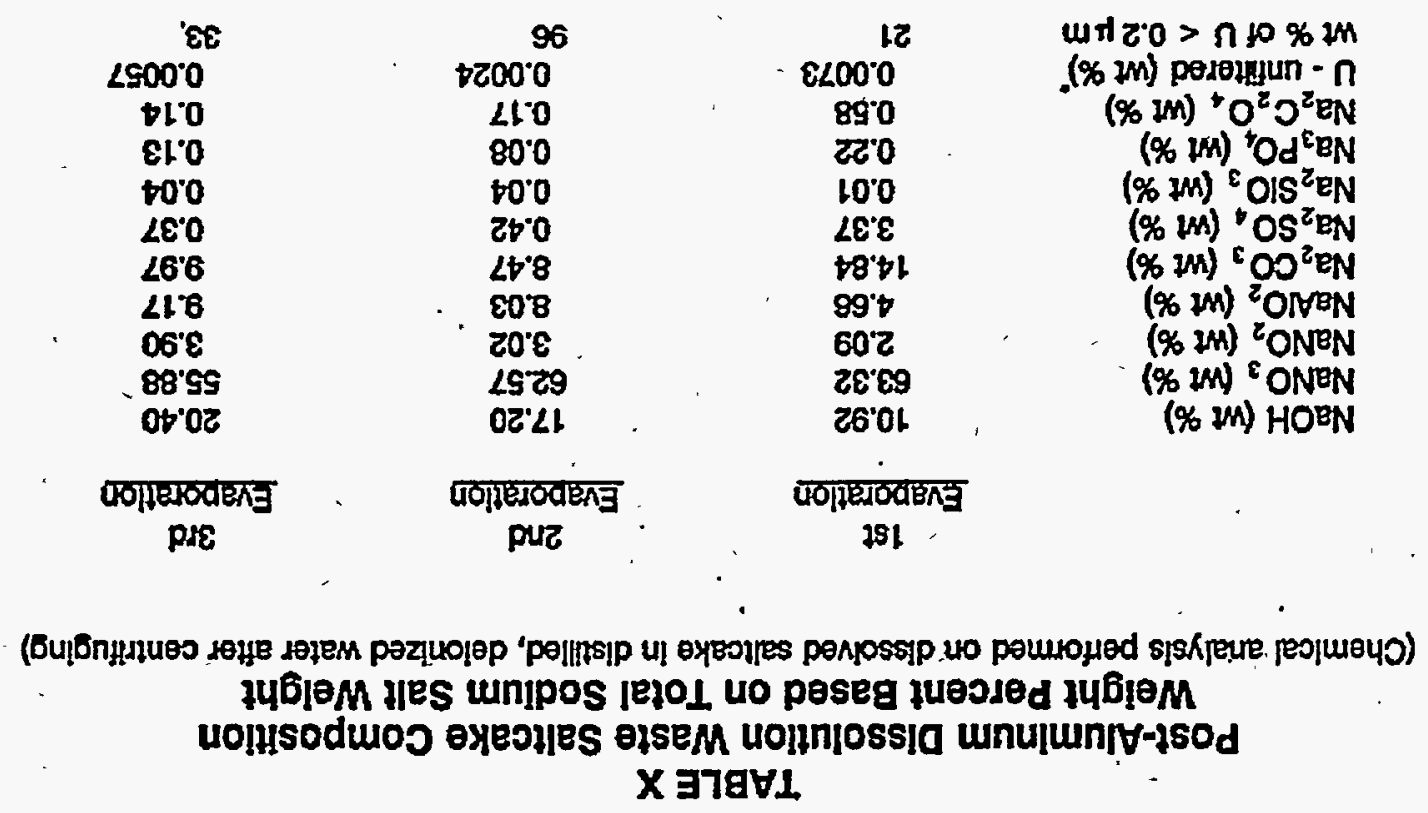

ISC+66-dY-O\&SM

$6 \mathrm{I}$ วึีย 
TABLE XII

Uranium Distribution in Low-Heat Waste

\begin{tabular}{|c|c|c|c|}
\hline & $\begin{array}{l}\text { 2nd Evaporation } \\
\text { (ut } \%)\end{array}$ & $\begin{array}{c}\text { 3rd Evaporation } \\
\text { (wt \&) }\end{array}$ & $\begin{array}{l}\text { 4th Evaporation } \\
\text { (ut \%) }\end{array}$ \\
\hline $\begin{array}{l}\text { wt \% of total } U \\
\text { (saltcake + supermate) } \\
\text { in saltcake and/or interstitial } \\
\text { liquid after centsfuging }\end{array}$ & 22 & 18 & 8 \\
\hline $\begin{array}{l}\text { Cumulathe wt } \% \text { of total U } \\
\text { (saltcake + supernate) } \\
\text { in saltcake and/or interstitial } \\
\text { liquld after centrfuging }\end{array}$ & 22 & 37 & 42 \\
\hline
\end{tabular}

TABLE XIII

Uranium Distribution in Post-Aluminum Dissolution Waste

wt \% of total U

(saltcake + supermate)

in saltcake or interstitlal

llquld

Cumulative wt \% of total $U$

(saltcake + supernate)

49
2nd Evaporation (ut \%)

22

19

liquid
49$$
\text { (ut os) }
$$ \\ 1st Evaporation
}

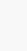

\section{n.}

\section{Wt \% of total $\mathrm{U}$}

+ supennato)

Page 20

\author{
(ust.8)
}

8 


\section{TABLE XIV
Low-Heat Waste Rinsed Saltcake Data}

Cumulative ut $\%$ of total U (in saltcake) dissoived

\begin{tabular}{|c|c|c|c|}
\hline $\begin{array}{l}\text { Rinse 1" } \\
\text { Rinse } 2^{*} \\
\text { Rinse } 3^{\circ} \\
\text { Remalning Saltcake* }\end{array}$ & $\begin{array}{c}\text { 2nd } \\
\text { ovaporation } \\
\text { (ut \%) } \\
34 \\
59 \\
84 \\
100\end{array}$ & $\begin{array}{l}\text { 3rd } \\
\text { ovaporation } \\
\text { (ut \%) } \\
45 \\
64 \\
87 \\
100\end{array}$ & $\begin{array}{c}\text { 4th } \\
\text { ovaporation } \\
\text { (wt \%) } \\
45 \\
70 \\
96 \\
100\end{array}$ \\
\hline
\end{tabular}

Cumulative ut \% of total saitcake dissolved

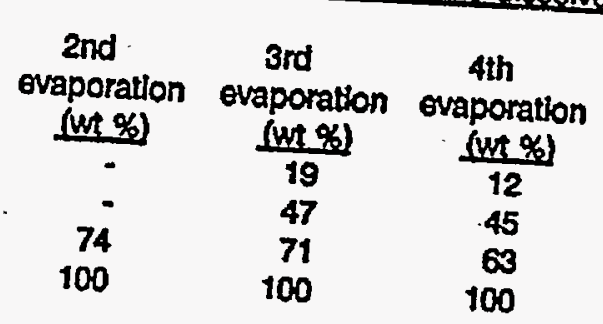

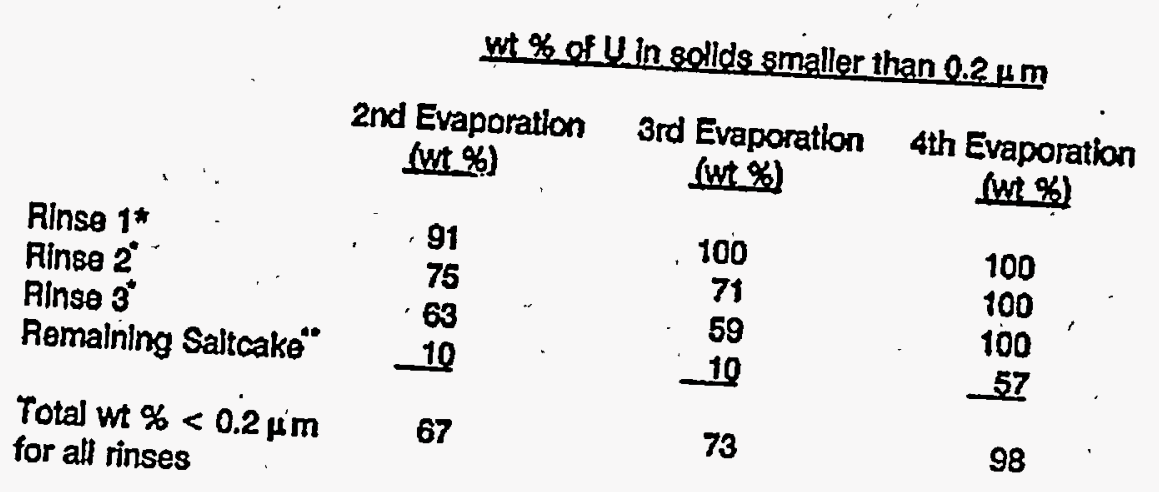

- not maasured

- Saltcake rinsed with $5 \mathrm{~mL}$ of high alkaline solution
- Remaining saltcake dlssolved in $25 \mathrm{~mL}$ distlled, delo 
Page 22.

WSRC-RP-94-251

\section{TABLE XV}

Post-Aluminum Dissolution Waste Ainsed Saltcake Data

Cumulative ut o of total $U$ in saltcakel dlosolved Cumulative wt of of total salteake olisselved

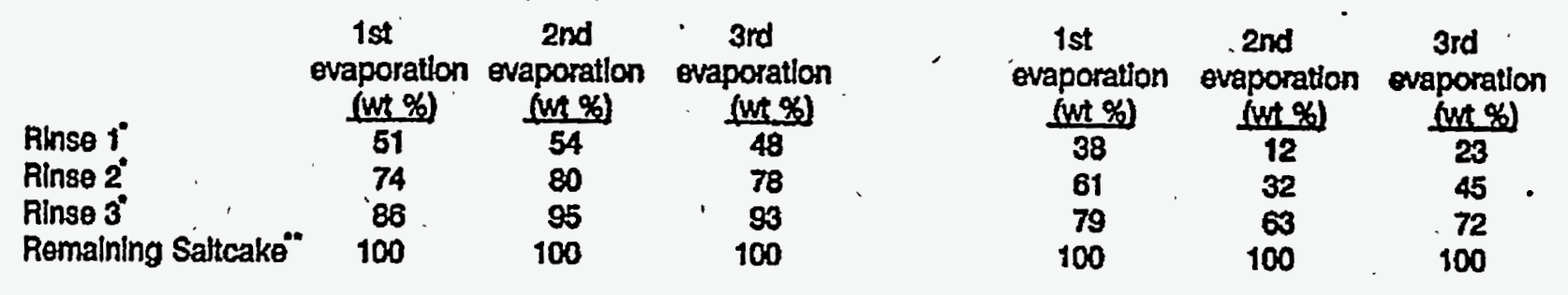

ut $\%$ of $U$ In solkds smaller than $0.2 \mu \mathrm{m}$

Ist Evaporation and Evaporation 3rd Evaporation

(ut \%) int \%) (iwt \%)

\begin{tabular}{|c|c|c|}
\hline $\begin{array}{l}\text { Rinse } 1^{*} \\
\text { Rinse } 2^{*} \\
\text { Pinse } 3^{*} \\
\text { Remaining Saltcake* }\end{array}$ & $\begin{array}{l}22 \\
29 \\
38 \\
17 \\
\end{array}$ & $\begin{array}{r}86 \\
92 \\
100 \\
50 \\
\end{array}$ \\
\hline $\begin{array}{l}\text { Total wh \% < }<0.2 \mu \mathrm{m} \\
\text { for all rinses }\end{array}$ & 25 & 88 \\
\hline
\end{tabular}

- Saltcake rinsed with $5 \mathrm{~mL}$ of hlgh alkallne solution

Rernaining saltcake dissolved in $25 \mathrm{~mL}$ distilled, delonized water 


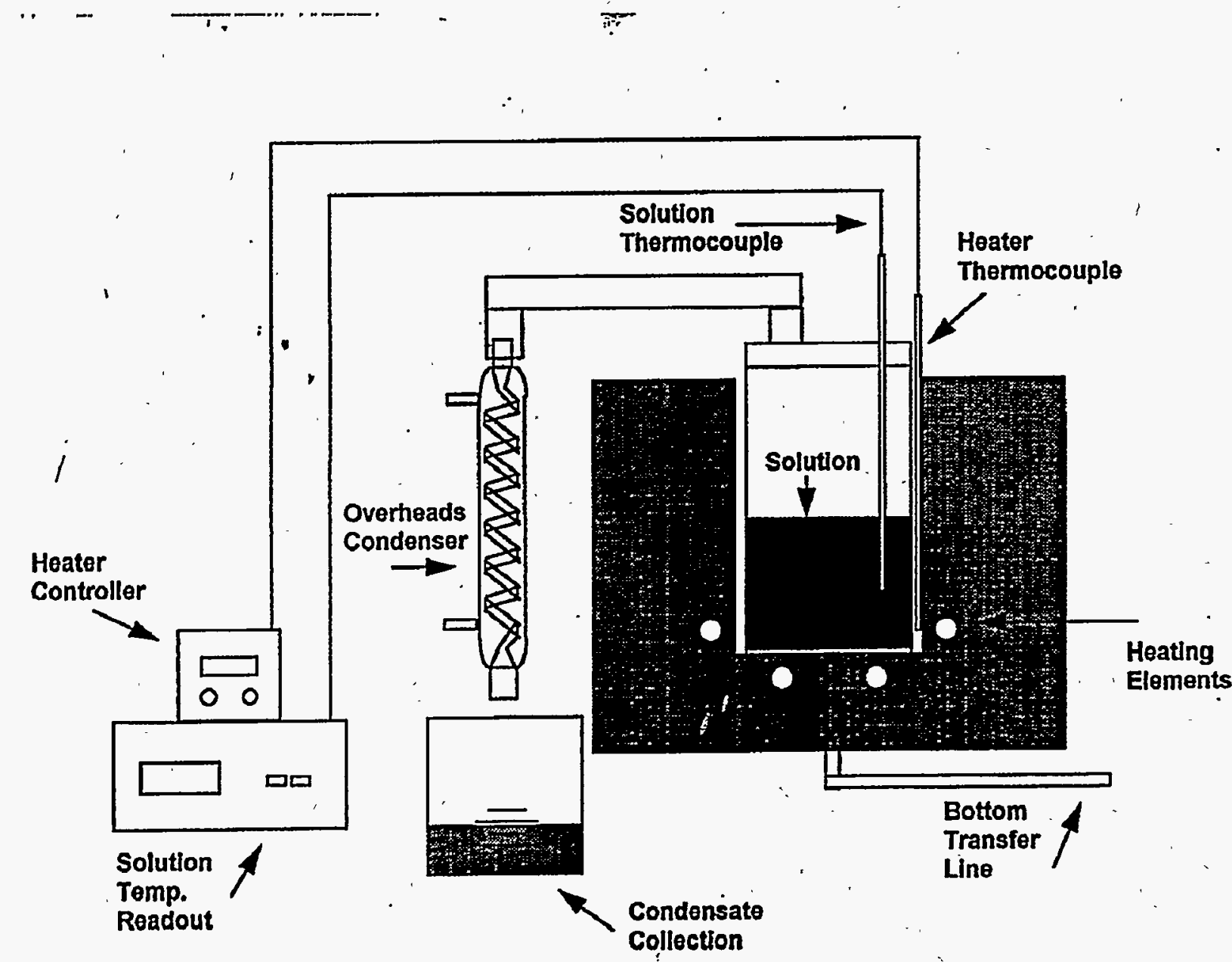

骂

Figure 1. Schematic of Evaporator Setup

".. 
Page 24

WSRC-RP-94-251

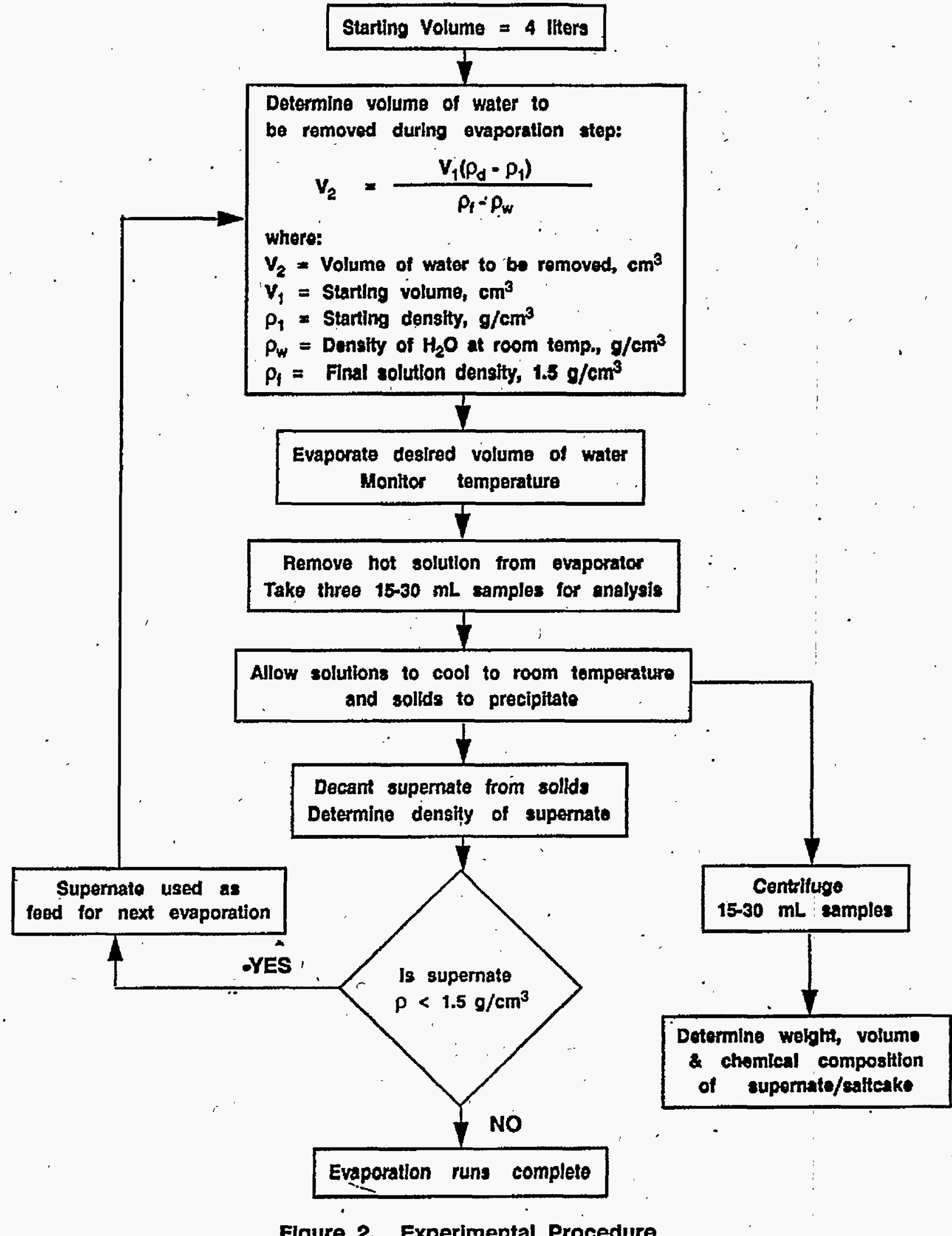

Figure 2. Experimental Procedure 


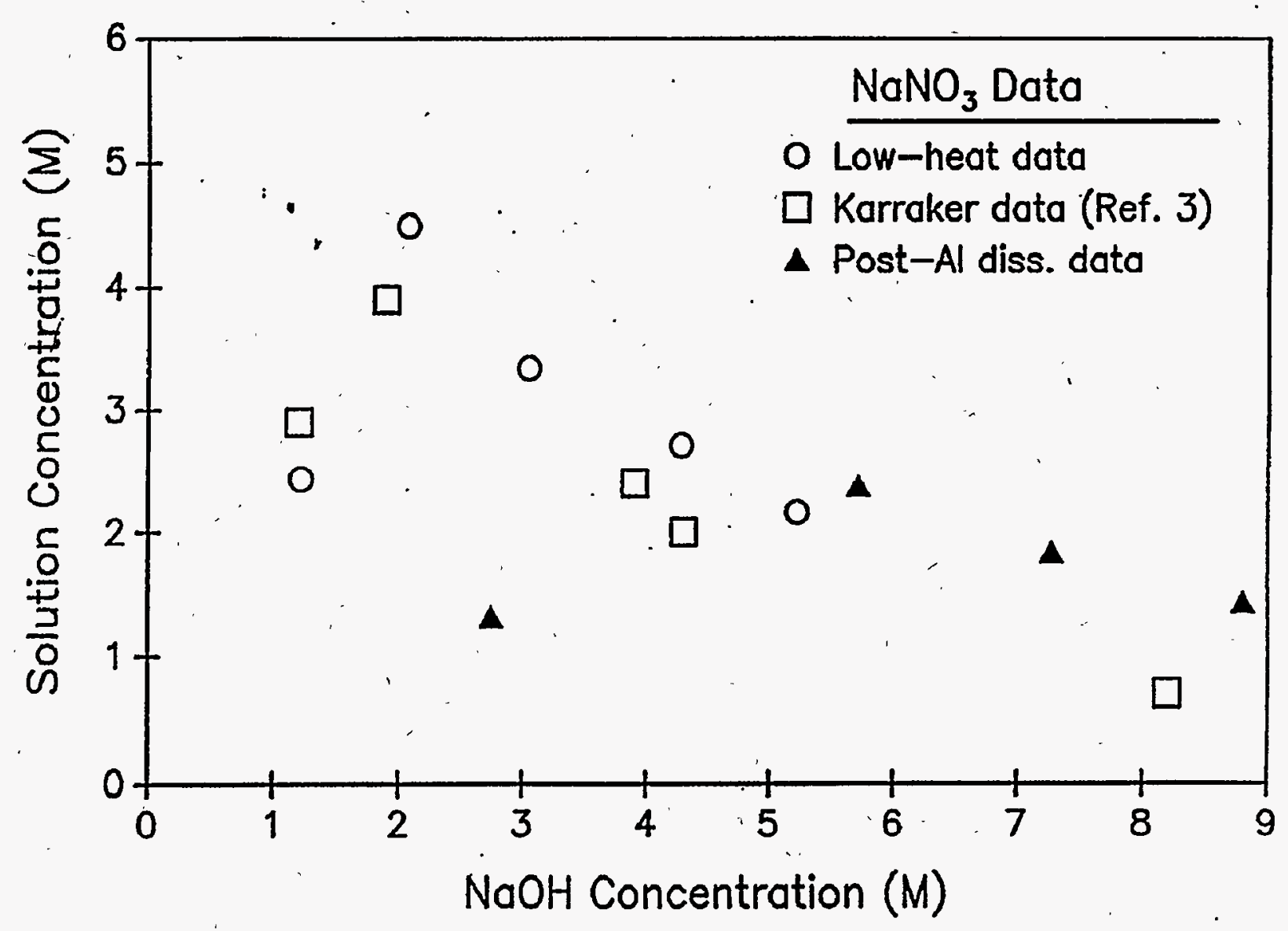

Figure 3. $\mathrm{NaNO}_{3}$ concentration vs. $\mathrm{NaOH}$ concentration 


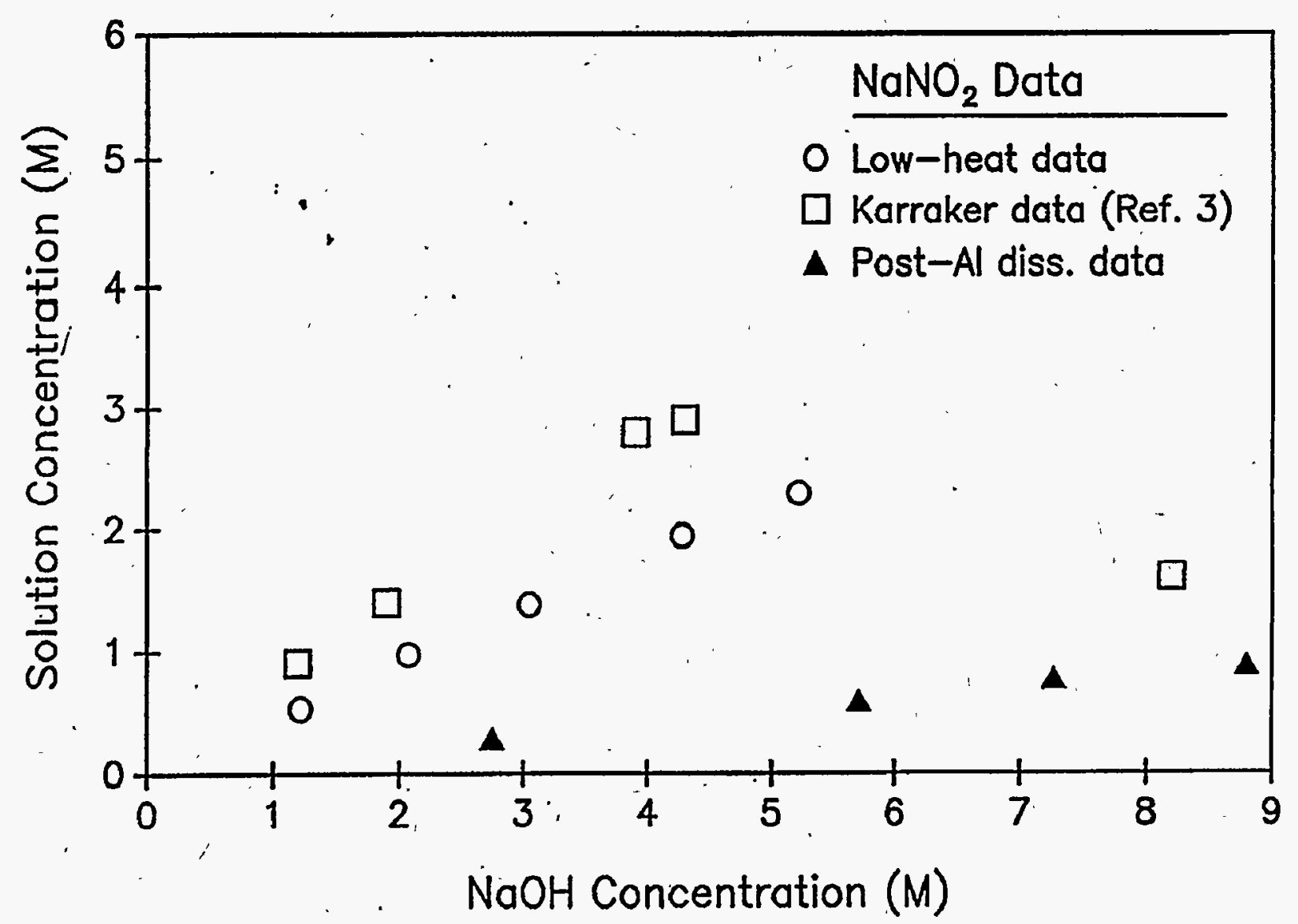

Figure 4. $\mathrm{NaNO}_{2}$ concentration vs. $\mathrm{NaOH}$ concentration 


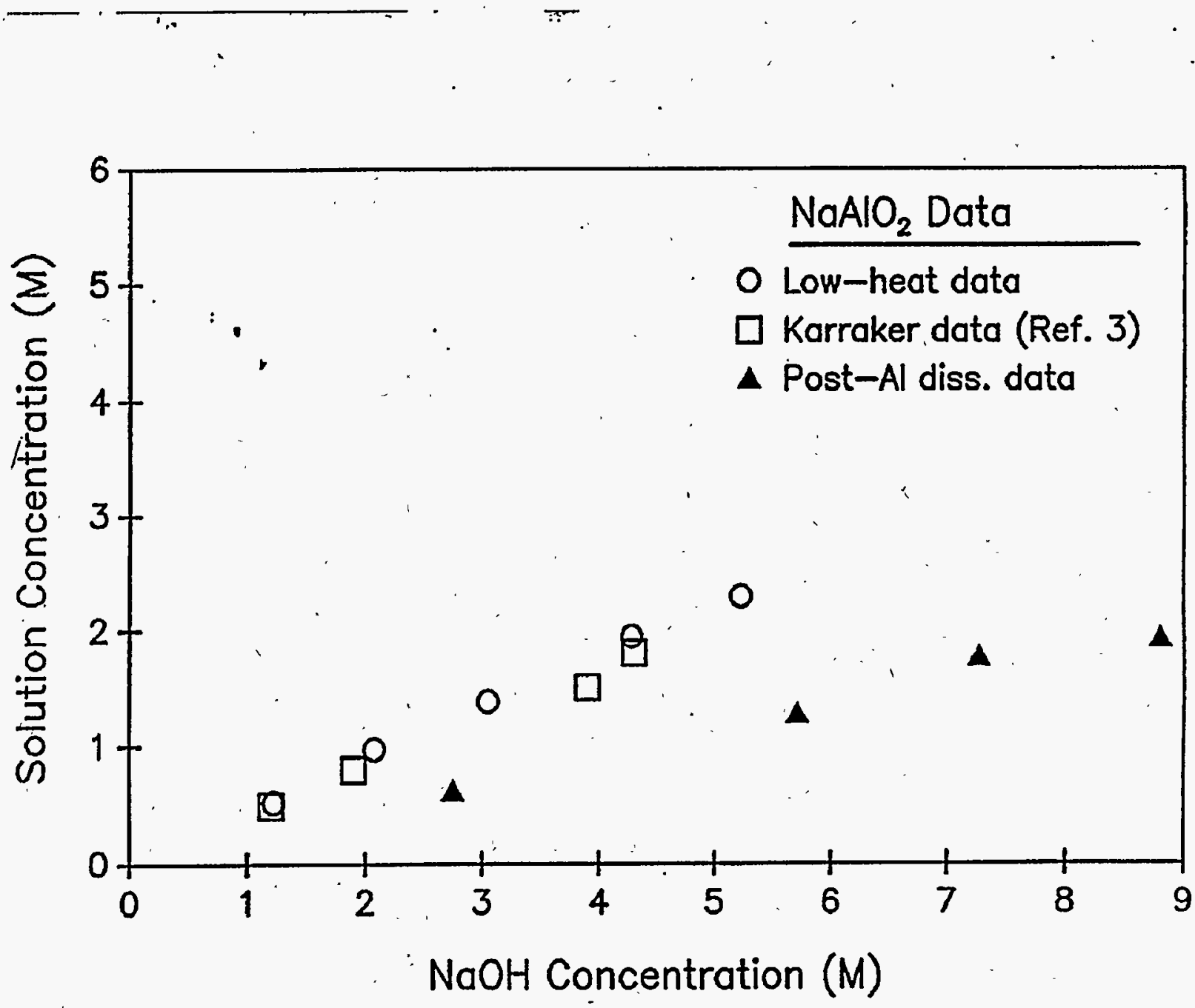

Figure 5. $\mathrm{NaAiO}_{2}$ concentration vs. $\mathrm{NaOH}$ concentration 


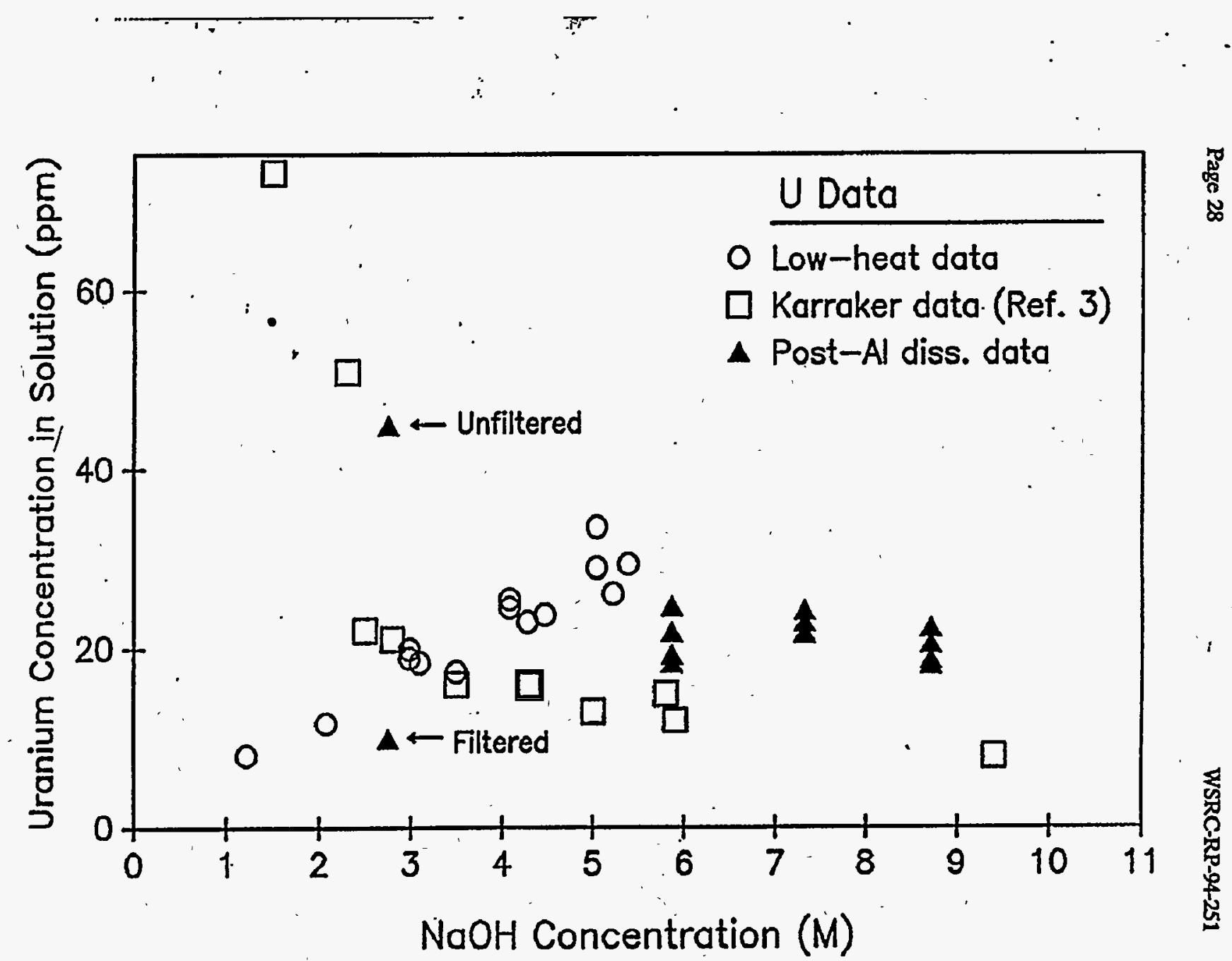

Figure 6. Uranium concentration v8. $\mathrm{NaOH}$ concentration 
Ratio of Cumulative Wt $\mathscr{x}$

Dissolved Uranium to Saltcake

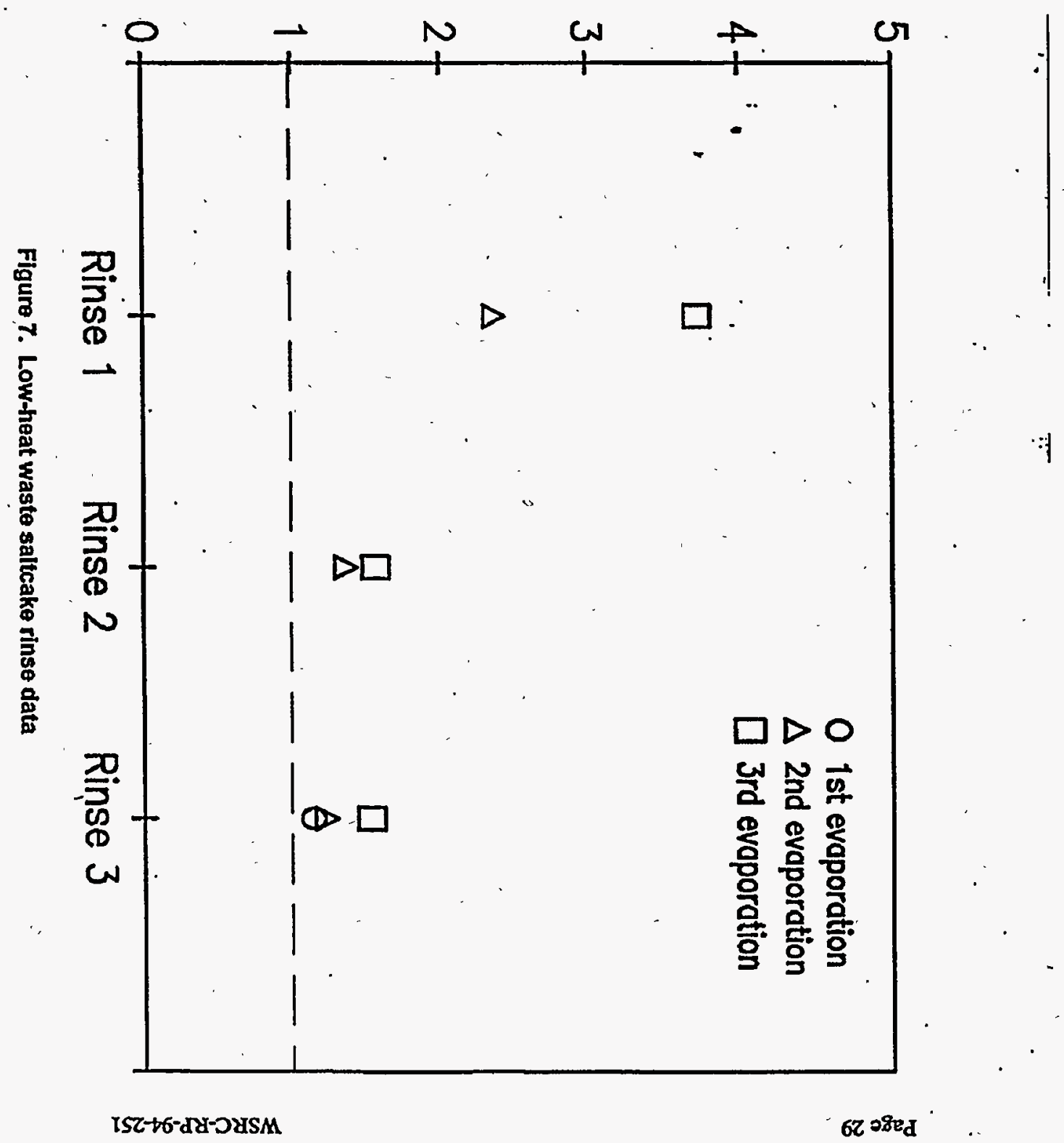




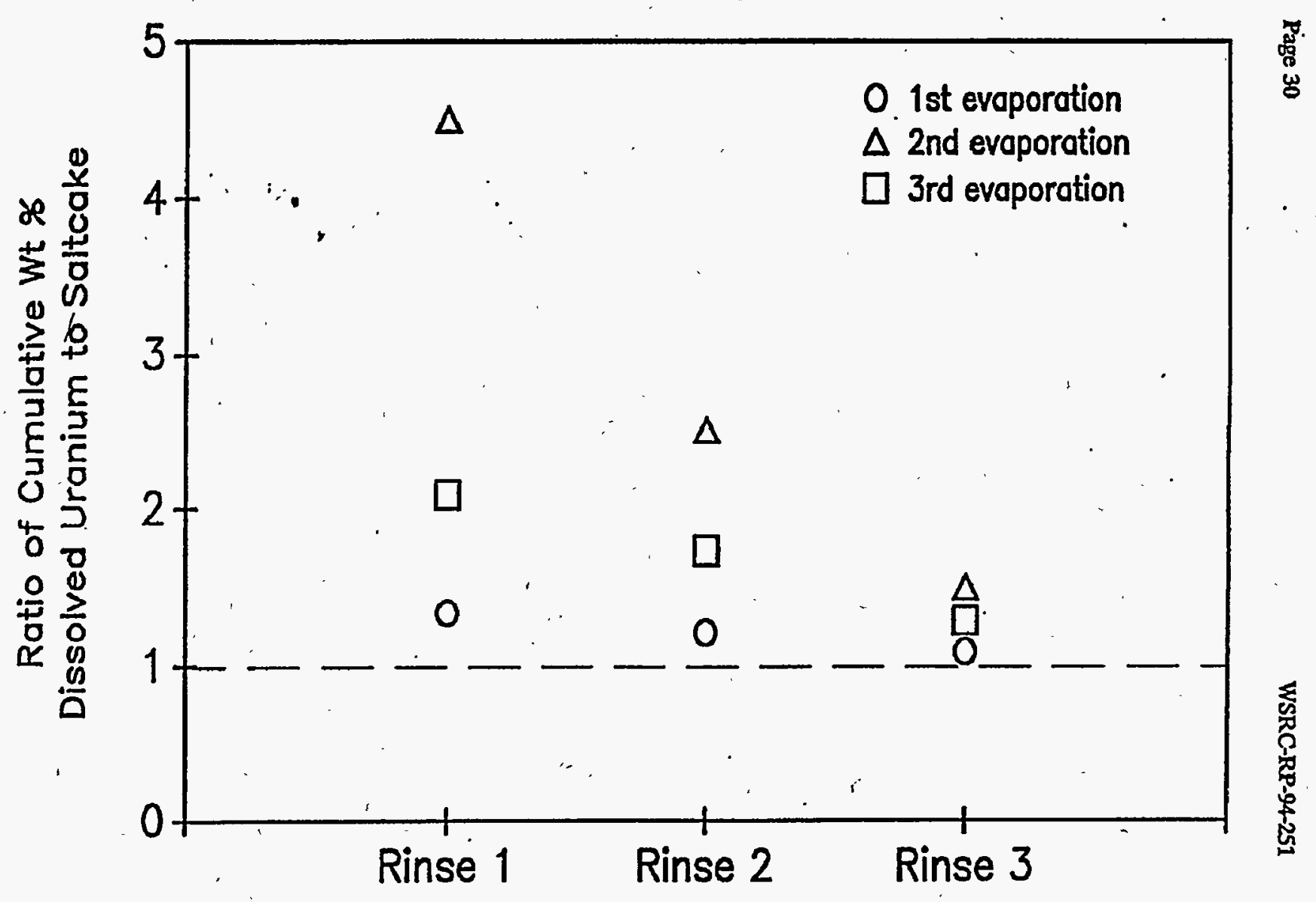

Figure 8. Post-aluminum dissolution saltcake rinse data 


\section{APPENDIX A}

\section{Evaporation Data Calculations}

The data for each evaporation step in Table III and Table VIII were calculated using the following equations:

vol \% evap. $=\frac{V_{w}}{V_{f}} \times 100$

vol \% reduction of feed $=\frac{v_{f}-V_{b}}{V_{f}} \times 100$

Cumulative vol $\%$ reduction of feed $=\frac{V_{\infty}-\left[\sum V_{\infty}+V_{s}\right]}{V_{a}}$

vol $\%$ swpemate in bottoms $=\frac{V_{\mathrm{a}}}{\mathrm{V}_{\mathrm{b}}} \times 100$

Density of supernate $=\frac{W_{s}}{V_{s}}$

vol \% saltcake in bottoms $=\frac{V_{\dot{c}}}{V_{b}}$

g Saltcake / L bottoms $=\frac{W_{c}(g)}{V_{b}(g)}$,

Density of saltcake $=\frac{-W_{s c}}{V_{s c}}$

wt $\mathscr{\%} \mathrm{H}_{2} \mathrm{O}$ in saltcake $=\frac{\mathrm{W}_{s c}-\mathrm{W}_{\mathrm{Na}_{\mathrm{B}}}}{\mathrm{W}_{* c}}$

wt $\%$ interstitial liquid in saltcake $=\frac{W_{w x}-W_{x}}{W_{x c}}$ 


\section{APPENDIX A \\ Evaporation Data Calculations (Cont'd)}

The following variables were determined for each evaporation step:

$V_{w}=$ Volume of water evaporated from feed solution

$V_{1}=$ Volume of feed solution (starting solution or supernate from previous step)

$V_{b}=$ Total volume of bottoms product after centrifuging Nolume of bottoms $=$ Volume of supernate + Volume of saltcake)

$V_{\mathrm{Be}}=$ Volume of starting solution (i.e. feed solution for first evaporation)

$V_{x c}=$ Volume of precipitated saltcake in bottoms product after centrifuging

$\Sigma V_{s c}=$ Cumulative volume of precipitated saltcake in bottoms product

$V_{3}=$ Volume of supernate in bottoms product after centrifuging

$W_{2}=$ Weight of starting solution or weight of supernate in bottoms product after centrifuging

$W_{10}=$ Weight of saltcake in bottoms product after centrifuging

$W_{\mathrm{Na}}=$ Weight of expected sodium salts based on chemical analysis of ions

$W_{\text {wse }}=$ Weight of saltcake in bottoms product before centrifuging

Supernate boiling point $\left({ }^{\circ} \mathrm{C}\right)=$ Boiling point of decanted supernate at time condensation of overheads began 